\title{
A set of high quality colour images with Spanish norms for seven relevant psycholinguistic variables: The Nombela naming test
}

\author{
Francisco Javier Moreno-Martínez ${ }^{1}$, Pedro R. Montoro' \& Keith R Laws ${ }^{2}$
}

\author{
${ }^{1}$ Departamento de Psicología Básica I, U.N.E.D. Madrid, Spain \\ ${ }^{2}$ School of Psychology, University of Hertfordshire, UK
}

Corresponding author:

Dr F. Javier Moreno-Martínez

U.N.E.D. Facultad de Psicología.

Departamento de Psicología Básica I

C/ Juan del Rosal, nº 10, 28040-Madrid. Spain.

Telephone: +34-91-3988853; Fax: +34-91-3987972.

E-mail: fjmoreno@psi.uned.es 


\begin{abstract}
This paper presents a new corpus of 140 high quality colour images belonging to 14 subcategories and covering a range of naming difficulty. One hundred and six Spanish speakers named the items and provided data for several psycholinguistic variables: Age of acquisition, familiarity, manipulability, name agreement, typicality and visual complexity. Furthermore, we also present lexical frequency data derived internet search hits. Apart from the large number of variables evaluated, these stimuli present an important advantage with respect to other comparable image corpora in so far as naming performance in healthy individuals is less prone to ceiling effect problems. Reliability and validity indexes showed that our items display similar psycholinguistic characteristics to those of other corpora. In sum, this set of ecologically-valid stimuli provides a useful tool for scientists engaged in cognitive and neuroscience-based research
\end{abstract}

Keywords: Ceiling effects, normative data, colour stimuli, nuisance variables, categoryspecific effects. 


\section{Introduction}

Three decades have passed since Snodgrass and Vanderwart (1980) presented their classic corpus of 260 line drawings. This corpus has been extensively used in clinical and experimental investigation on cognitive processing and, undoubtedly has proved to be a useful tool for researchers examining language, memory and object processing. Nevertheless, recent investigations have revealed some limitations in the aforementioned corpus. For example, from an ecological view, the validity of studies using black and white line drawing have been questioned by some authors (Viggiano, Vannucci, \& Righi, 2004). Colour is an essential attribute of objects and for some specific objects, forms a defining property (Adlington, Laws \& Gale, 2009; Price \& Humphreys, 1989; Tanaka \& Presnell, 1999). Indeed, colour generally confers recognition advantages (Adlington et al., 2009; Price \& Humphreys, 1989; Tanaka \& Presnell, 1999; Wurm, Legge, Isenberg, \& Luebker, 1993) and improves naming accuracy for objects judged to have high colour-diagnosticity (Oliva \& Schyns, 2000; Tanaka \& Presnell, 1999) i.e. characterised by a specific colour: for example, carrots are invariably orange. Additionally, surface detail, whether coloured or not, seems to play a key role in our ability to recognise living things, possibly because, for example, animals (and fruits and vegetables) tend to be more structurally similar to each other, and have higher colour diagnosticity (Adlington et al., 2009; Price \& Humphreys, 1989; Tanaka $\&$ Presnell, 1999). Accordingly, the number of studies using coloured stimuli has been progressively increasing (e.g. Adlington, Laws, \& Gale, 2008; Zannino, Perri, Salamone, Di Lorenzo, Caltagirone, \& Carlesimo, 2010).

One constraint of the Snodgrass and Vanderwart corpus (S\&V) relates to later developments that highlight new and important psycholinguistic variables relevant to 
the study of cognitive-linguistic mechanisms. In recent years, researchers have documented several variables that should be taken into account in any study focused on picture or word processing. For example, "age of acquisition" (AoA) has been shown to be a powerful predictor of object naming performance in both normal and brain-injured individuals (Holmes, Fitch, \& Ellis, 2006). Similarly, several authors have supported the occurrence of a significant relationship between the degree of manipulability of an object and its semantic representation (e.g., Allport, 1985; Buxbaum \& Saffran, 2002; Magnié, Besson, Poncet, \& Dolisi 2003; Tranel, Logan, Randall, \& Damasio, 1997; Warrington \& McCarthy, 1987). Indeed, fMRI studies suggest that certain brain areas selectively responsive to the processing of manipulable objects (e.g. Beauchamp, Lee, Haxby, \& Martin, 2002; Beauchamp, Lee, Haxby, \& Martin, 2003; Kellenbach, Brett, \& Patterson, 2003; Martin 2007). Furthermore, differences in manipulability may partly explain category effects on object identification, i.e., a better performance with items from nonliving things domain (e.g., tools) compared to living things (e.g., animals; see Capitani, Laiacona, Mahon, \& Caramazza, 2003, for a review). To our knowledge, two recent studies have provided ratings of AoA (Adlington et al., 2008) or manipulability (Magnié et al., 2003) but not both AoA and manipulability concurrently.

A line of research conducted by Laws and collaborators have highlighted the common occurrence of ceiling effects in studies examining naming with stimuli from the S\&V (see Laws, 2005; Laws, Gale, Leeson, \& Crawford, 2005). As accumulated evidence has shown in the last decades, most of the items from the $S \& V$ are easily named by healthy participants, at least under normal viewing conditions. Laws and colleagues have shown that comparison of control data, which is at ceiling, to that of neurologically impaired patients may distort both the degree and type of deficit reported 
in patients (Laws, 2005; Laws et al., 2005). Furthermore, in recent developments of both the S\&V as colour images (Rossion \& Pourtois, 2004), and of new stimuli sets (Viggiano et al., 2004) the naming performance of neurologically intact participants on these images is, if anything, closer to ceiling.

Finally, we note that despite the large and increasing number of Spanish speakers across the world, few neuropsychological tests have been devised in Spanish and those that do exist, are translations of English tests. Limited work has examined the factors affecting naming in non-English languages. Obviously, models of object recognition are assumed to have universal application and so, comparative data from other languages and cultures are crucial. While some variables e.g. familiarity and visual complexity tend to yield high cross-language correlations (see Pompéia, Miranda, \& Bueno, 2003), other crucial variables, such as name agreement may be more language specific (Sanfeliú \& Fernández, 1996). Furthermore, with the increasing numbers of people suffering from Alzheimer and other forms of dementia, it is necessary to have naming tests and norms that are culturally and linguistically appropriate for use with the elderly.

The goal of the present work was twofold: (1) to present a new set of high quality colour photographs on white backgrounds covering a range of item difficulty to avoid ceiling effects in healthy participants; and (2) to provide detailed norms, derived from a group of healthy participants, for the following relevant psycholinguistic variables: AoA, familiarity, manipulability, name agreement, typicality and visual complexity, as well as lexical frequency. 


\section{Methods}

\section{Item selection}

We selected 14 semantic subcategories for theoretical and methodologically relevant reasons (Moreno-Martínez, Laws, \& Schultz, 2008). For example, we included problematic/atypical subcategories, such as body parts and musical instruments (Barbarotto, Capitani, \& Laiacona, 2001; Laws, Gale, Frank \& Davey 2002); plant life subcategories, such as flowers, fruits, trees and vegetables (Caramazza \& Shelton, 1998) as well as subcategories differing in their degree of manipulability, such as buildings, kitchen utensils or tools (Magnié et al., 2003). Consequently we included seven subcategories from the living domain: animals, body parts, insects, flowers, fruits, trees and vegetables, and seven from the nonliving domain: buildings, clothing, furniture, kitchen utensils, musical instruments, tools and vehicles. This range of subcategories is in line with those initially presented by Snodgrass and Vanderwart (1980); and certainly covers a wider range than some other recent picture corpora. For example, the Bank of Standardised Stimuli (BOSS: Brodeur, Dionne-Dostie, Montreuil \& Lepage (2010), which excludes animals, vehicles body parts and buildings; and Viggiano et al. (2004) also exclude body parts and buildings and while they provide normative information for colour and greyscale images, unfortunately this is limited to ratings for familiarity and visual complexity.

Following the aforementioned procedure, a total of 140 items were selected, with ten per category. Subsequently, colour photographs were obtained for each selected item. Most of the photographs were taken by the first author and a few were donated by friends and colleagues. Images were removed from their original backgrounds and placed on a plain white background; mean dimension of images was 265 x 223 pixels. 
Regarding the left-right orientation of each image, it was decided that, of each category susceptible of being oriented (i.e. animals, vehicles or tools), half of the items were leftfacing and the other half right-facing.

The aforementioned images were displayed to a sample of 106 participants (see Participants section) for naming and, then, for evaluating five psycholinguistic variables: AoA, familiarity, manipulability, typicality and visual complexity. The set of items are readily available on request from the first author of this study (fjmoreno@psi.uned.es). Examples of images from the corpus appear in Figure 1.

Figure 1. Examples of the standardized stimuli (one for each category).

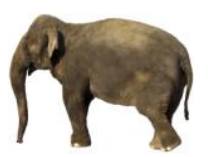

Elephant (Animals)

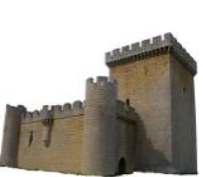

Castle (Buildings)

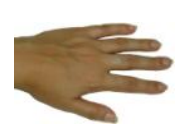

Hand

(B. parts)

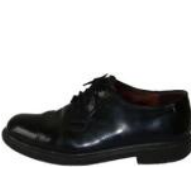

Shoe

(Clothing)

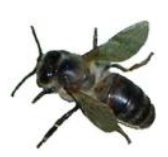

Bee

(Insects)

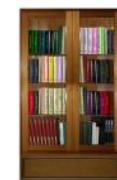

Bookcase (Furniture)

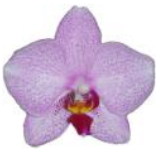

Orchid

(Flowers)

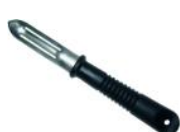

Peeler (Kitchen ut.)

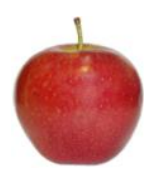

Apple

(Fruits)

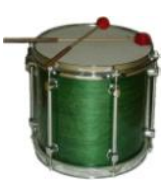

Drum

(Musical inst.)

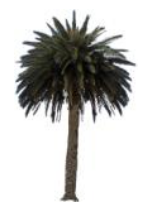

Palm tree

(Trees)

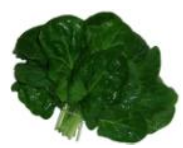

Spinach

(Vegetables)

\section{Participants}

The sample consisted of 106 healthy Spanish speakers undergraduate students (53 males: 53 females) with a mean age 32.9 years $(\mathrm{SD}=8.9$; range 20-52 years; Males $\mathrm{M}$ 
$=34.4, \mathrm{SD}=7.3$; Females $\mathrm{M}=31.5 \mathrm{SD}=10.2, \mathrm{t}(104)=1.7$, n.s. $)$ and a mean number of years of education of 13.8 years $(\mathrm{SD}=2.5$; range $8-18$ years; Males $\mathrm{M}=14.1, \mathrm{SD}=$ 2.6; Females $\mathrm{M}=13.7, \mathrm{SD}=2.4, \mathrm{t}(104)=1$, n.s.). All had normal or corrected-tonormal vision, and Spanish was their first language. Any person with a known history of neurological disease, head trauma, or stroke was excluded. The student participants were assigned course credit for their participation in the study.

\section{Procedure}

Participants were tested individually in two sessions. They all first carried out the naming session and, subsequently, they rated the items for: familiarity, age of acquisition, visual complexity, manipulability and typicality. Testing lasted approximately ninety minutes, with self-administered rest periods during the two sessions and between sessions. Each experimental session was preceded by the instructions provided by researchers and a practice phase to enable each participant to become familiar with the task and to generate the acquisition of anchor points for the stimulus ratings. Each participant observed ten pictures in the practice phase, none of them included in the main stimulus set. The pictures were displayed on a colour monitor with a screen resolution of $1024 \times 768$ controlled by a microcomputer running E-Prime 1.1 software (Psychology Software Tools, 1996-2002). Viewing distance was approximately $60 \mathrm{~cm}$.

During the test phase, the 140 images were presented in a random order. Each image was preceded by a cross (+) for $500 \mathrm{~ms}$, and remained on the screen for 3,000 ms (naming task phase) or until the participant responded during the item rating phase). Initially, participants performed the naming task and then evaluated the following 
variables: AoA, familiarity, manipulability, typicality and visual complexity. During this latter part, visual complexity and typicality were always the first and the last variables evaluated respectively; the rest of the variables were randomly displayed. To evaluate visual complexity, participants were asked to "rate the visual complexity of the image itself, rather than that of the object it represents". To evaluate the remaining variables (AoA, familiarity, manipulability and typicality), participants were asked to "rate the object represented rather than the image itself". When the participants evaluated the variables AoA, familiarity, manipulability and typicality, experimenters provided them with the canonical name of the item. Additionally, when participants evaluated the typicality of the items, they were also provided with the category of the item on the screen (e.g., "animals" -category- for "elephant"-item-).

Naming task: Participants were asked to name each image by typing its name with the keyboard on the screen. They were told to give the specific -rather than general- name for the different items. For example, in case of the subcategory of "trees", if participant knew the name of the item, he/she should give the name of that particular tree, e.g. "pine tree", instead of the general name of "tree". Participants were asked to write the initials for "don't know" (NC = "No Conozco", in Spanish), if the image was unknown to them, to say "tip of the tongue" (PL = "Punta de la Lengua", in Spanish) if they were momentarily unable to remember the name, or to say "don't remember" (NR = "No Recuerdo", in Spanish). All their responses were automatically saved by the program. According to this task, "name agreement" was calculated based on the percentage of participants who named the item according to canonical name. 
Visual Complexity: Instructions from Snodgrass and Vanderwarts' study were adapted to evaluate the visual complexity of the items. Consequently, participants were asked to evaluate "the amount of detail, intricacy of lines, pattern and quantity of colours presented in the image". Participants recorded their responses on a 5-point scale $(1=$ very simple, 5 = very complex) by pressing corresponding numbers on a keyboard.

AoA: Participants were asked to estimate the age in years at which they had learned each word following the same procedure that other similar previous studies (e.g., Gilhooly \& Gilhooly, 1979; Silveri, Cappa, Mariotti, \& Puopolo, 2002). Scores were obtained by asking participants to rate age of acquisition for each word on a seven-interval scale (range: 1 = 0-2 years; 7 = 13 years or more; see Moreno-Martínez \& Peraita, 2007). Familiarity: Participants were instructed to rate each item, assessing "how usual or unusual the concept is in your realm of experience" on the basis of "how frequently you think about the concept, and how frequently you come into contact with the concept -both in a direct way (e.g. seeing a real-life exemplar), and in a mediated way (e.g. represented in the media)". Participants provided their responses on a 5-point Likert scale $(1=$ very unfamiliar, $5=$ very familiar $)$ by pressing the corresponding number on a keyboard.

Manipulability: Participants were instructed to rate each item, assessing "the degree to which using a human hand is necessary for this object to perform its function". Participants provided their responses on a 5-point Likert scale $(1=$ never necessary, $5=$ totally indispensable) by pressing the corresponding number on the keyboard. 
Typicality: This reflects the degree a concept is a representative exemplar of its category. Scores were obtained by asking participants to rate on a 5 -point scale $(5=$ very prototypical) how representative of its category they think an exemplar was (e.g. car for vehicles).

Lexical frequency: Owing to the unavailability of norms for all of the item words in a standard Spanish corpus (e.g. Sebastián, Martí, Carreiras, \& Cuetos, 2000), we gathered norms for lexical frequency using an internet search engine. This method is a viable alternative to the currently available databases and may even provide a more representative (Blair, Urland, \& Ma, 2002) as well as a constantly updating measure of word frequency (Adlington et al., 2008) that has high convergent validity with other more classical databases. Furthermore, search engines permit the gathering of word frequency values for more unusual items that do not typically feature in conventional databases (see Adlington et al., 2008; Baayen, Piepenbrock, \& Gulikers, 1995; Kucera \& Francis, 1967). With more than 250 million web pages, the AltaVista search engine (www.altavista.com) is one of the largest search engines currently available and for this reason, it was selected for this process. These names were entered into the search function of AltaVista, and a search performed specifying that results should be for Spain and in Spanish only. The number of hits returned, after conversion to their natural logarithm, served as the frequency estimate for each word (Adlington et al., 2008; Blair et al., 2002). 


\section{Results}

1. Descriptive results.

A summary of the rating data for each item are reported in Appendix A. In addition, participants were divided in two groups by using age median value to split the sample. Accordingly, Appendix B shows separated mean ratings obtained from the two agedbased groups: 20-33 years old $(n=50)$ and $34-52$ years old $(n=56)$. "Don't know", "tip of the tongue" and "don't remember" responses were not taken into account in the computation of ratings. For each item, the following information is presented: 1) most frequent name in English and Spanish, 2) two measures of name agreement: the statistic $H$ and the percentage of participants producing the canonical name. Although both indexes are measures of name agreement, the latter indicates only how dominant the most common name is in a sample; whilst $H$ is sensitive to how widely distributed responses are over all the unique names that are provided for a picture. Consequently, the $H$ index is more informative than name agreement (e.g., it gives information about the dispersion of the names). $H$ was calculated according to the following formula:

$$
H=\sum_{i=1}^{k} \mathrm{p}_{i} \log _{2}\left(\frac{1}{p_{i}}\right)
$$

where $\mathrm{k}$ is the number of unique names given for a picture, and pi is the proportion of the sample providing each unique name. $H=0$ when there is perfect agreement among participants (e.g., just one name) and increases as agreement decreases. 3) the means and standard deviation for AoA, Familiarity, Manipulability, Typicality and Visual Complexity, 4) Lexical Frequency values expressed as natural logarithm, 5) category and domain of the items. Appendix $\mathrm{C}$ reports the proportion of target names, acceptable 
synonyms -according to Spanish grammatical rules- and alternative names of each item. Appendix D presents indexes of individual item analysis, including a measure of item difficulty and two indexes of item discrimination based on item-test correlations: pointbiserial and biserial. Table 1 presents summary statistics for all the mentioned variables. Likewise, Table 2 shows summary statistics for all the variables for all the subcategories.

Table 1. Summary statistics for all the variables.

\begin{tabular}{lrrrrrrrr}
\hline & AoA & Fam & LF $(\log )$ & Man & Tip & VC & NA & \multicolumn{1}{c}{$H$} \\
\hline$M$ & 4.3 & 3.1 & 14.6 & 2.9 & 3.4 & 2.7 & 0.6 & 1.3 \\
SD & 1.6 & 1.1 & 2.3 & 1.3 & 1.2 & 0.7 & 0.3 & 0.9 \\
Median & 4.4 & 3.1 & 14.5 & 3.1 & 3.5 & 2.7 & 0.7 & 1.3 \\
Mode & 4.3 & 1.9 & 14.8 & 1.2 & 1.6 & 2.9 & 1 & 0 \\
Skew & -0.2 & 0.5 & -1.1 & 0.1 & -0.3 & 0.2 & -0.4 & 0.2 \\
Kurtosis & -1.2 & -1.1 & 4.9 & -1.4 & -1.3 & -0.7 & -1.3 & -1.1 \\
Range & 5.6 & 3.7 & 18 & 3.9 & 3.8 & 3.2 & 0.9 & 3.5 \\
Min & 1.3 & 1.2 & 2.2 & 1.1 & 1.2 & 1.2 & 0 & 0 \\
Max & 6.9 & 4.9 & 20.2 & 4.9 & 4.9 & 4.4 & 1 & 3.5 \\
Q1 & 2.9 & 2.2 & 13.5 & 1.5 & 2.3 & 2.1 & 0.3 & 0.3 \\
Q3 & 5.9 & 3.9 & 15.9 & 4.1 & 4.5 & 3.3 & 0.9 & 2 \\
\hline
\end{tabular}

Note: $\mathrm{AoA}=$ Age of acquisision; Fam = Familiarity, LF = Lexical frequency $(\log )$; Man = Manipulability; Tip $=$ Typicality $;$ VC $=$ Visual complexity $\%$ NA $=$ Percentage of name agreement. 
Table 2. Summary statistics for all the variables for each category.

\begin{tabular}{lcccccccccccccc}
\hline & \multicolumn{1}{c}{ AoA } & \multicolumn{1}{c}{ Fam } & \multicolumn{1}{c}{ Man } & \multicolumn{1}{c}{ Typicality } & \multicolumn{3}{c}{ VC } & \multicolumn{3}{c}{ LF $(\log )$} & \multicolumn{3}{c}{ NA } \\
\hline Animals & $\boldsymbol{M}$ & $\boldsymbol{S D}$ & $\boldsymbol{M}$ & $\boldsymbol{S D}$ & $\boldsymbol{M}$ & $\boldsymbol{S D}$ & $\boldsymbol{M}$ & $\boldsymbol{S D}$ & $\boldsymbol{M}$ & $\boldsymbol{S D}$ & $\boldsymbol{M}$ & $\boldsymbol{S D}$ & $\boldsymbol{M}$ & $\boldsymbol{S D}$ \\
Body parts & 3.9 & 1.9 & 2.7 & 1.3 & 1.3 & 0.4 & 3.3 & 1.4 & 3.1 & 0.4 & 15 & 1.9 & 0.7 & 0.3 \\
Flowers & 3.9 & 1.9 & 3.4 & 1.1 & 1.5 & 0.7 & 3.6 & 0.9 & 2.7 & 0.8 & 15.8 & 2.1 & 0.6 & 0.3 \\
Fruits & 4.4 & 1.3 & 3.2 & 0.8 & 1.7 & 0.2 & 3.7 & 0.9 & 2.8 & 0.6 & 15.5 & 1.9 & 0.6 & 0.3 \\
Insects & 4 & 1.8 & 3.4 & 1.3 & 3.3 & 0.3 & 3.4 & 1.2 & 1.9 & 0.5 & 14.4 & 1.1 & 0.6 & 0.4 \\
Trees & 2.9 & 1.1 & 3.6 & 0.8 & 1.2 & 0.1 & 4.2 & 0.7 & 2.9 & 0.5 & 14.9 & 1.3 & 0.8 & 0.2 \\
Vegetables & 4.4 & 0.9 & 3.1 & 0.5 & 1.5 & 0.3 & 3.7 & 0.5 & 2.7 & 0.5 & 15.2 & 0.9 & 0.5 & 0.3 \\
& 4.3 & 0.8 & 3.5 & 0.7 & 3.4 & 0.1 & 3.7 & 0.6 & 2.3 & 0.3 & 14.4 & 0.6 & 0.7 & 0.2 \\
Buildings & 4.6 & 1.7 & 2.5 & 1.1 & 2.2 & 0.3 & 2.6 & 1.3 & 3.3 & 0.8 & 15.2 & 2.9 & 0.7 & 0.3 \\
Clothing & 4.8 & 1.9 & 2.7 & 1.4 & 3.4 & 0.6 & 2.6 & 1.4 & 2.2 & 0.8 & 12.8 & 2 & 0.6 & 0.4 \\
Furniture & 4.4 & 1.7 & 3.6 & 1.1 & 2.9 & 0.6 & 3.4 & 1.1 & 2.9 & 0.7 & 15.1 & 2 & 0.6 & 0.3 \\
Kitchen ut. & 5.1 & 1.6 & 2.9 & 1.3 & 4.3 & 0.3 & 2.9 & 1.3 & 2.4 & 0.6 & 13 & 4.3 & 0.5 & 0.4 \\
Musical inst. & 4.7 & 1.5 & 2.6 & 0.9 & 4.8 & 0.1 & 3.6 & 1.1 & 3.5 & 0.7 & 14.3 & 2.2 & 0.7 & 0.4 \\
Tools & 5.1 & 1.5 & 2.8 & 0.9 & 4.7 & 0.1 & 3.4 & 1.1 & 2.0 & 0.3 & 12.6 & 2.3 & 0.5 & 0.4 \\
Vehicles & 4.2 & 2.3 & 3.1 & 1.5 & 4.1 & 0.4 & 2.9 & 1.6 & 3.4 & 0.5 & 15.7 & 2.8 & 0.5 & 0.4 \\
\hline
\end{tabular}

Note: $\mathrm{AoA}=$ Age of acquisision; Fam = Familiarity, LF = Lexical frequency $(\log ) ;$ Man = Manipulability; Tip = Typicality; VC = Visual complexity; \% NA = Percentage of name agreement.

\section{Correlation among measures.}

Pearson correlations revealed that naming (name agreement and $H$ index) correlated highly and significantly with most of the psycholinguistic variables (see Table 3).

Nevertheless, two exceptions emerged, with neither visual complexity nor manipulability correlating with name agreement and the $H$ index. Indeed, manipulability failed to correlate with any variable except for lexical frequency. 
Table 3. Correlation matrix for naming performance and psycholinguistic variables.

\begin{tabular}{|c|c|c|c|c|c|c|c|c|}
\hline & AoA & Fam & $\mathbf{L F}$ & Man & Tip & VC & $\% \mathrm{NA}$ & $\boldsymbol{H}$ \\
\hline AoA & 1 & $-.91 *$ & $-.68^{*}$ & .16 & $-.91 *$ & $-.26^{*}$ & $-.79 *$ & $.75^{*}$ \\
\hline Fam & & 1 & $.65^{*}$ & -.04 & $.92 *$ & -.33 & $.75^{*}$ & $-.69 *$ \\
\hline $\mathbf{L F}$ & & & 1 & $-.23^{*}$ & $.63^{*}$ & -.03 & $.54 *$ & $-.5^{*}$ \\
\hline Man & & & & 1 & -.07 & -.13 & -.04 & -.02 \\
\hline Tip & & & & & 1 & $-.26^{*}$ & $.73 *$ & $-.66^{*}$ \\
\hline VC & & & & & & 1 & -.10 & .10 \\
\hline NA & & & & & & & 1 & $-.89 *$ \\
\hline $\boldsymbol{H}$ & & & & & & & & 1 \\
\hline
\end{tabular}

Note: $\mathrm{AoA}=$ Age of acquisision; Fam = Familiarity, $\mathrm{LF}=$ Lexical frequency; Man = Manipulability; Tip = Typicality $; \mathrm{VC}=$ Visual complexity $\%$ NA $=$ Percentage of name agreement.

$* p<.01$

\section{Living/Nonliving differences.}

An ANOVA was used to establish the extent to which living/nonliving statistical differences for the seven variables were presented. Table 4 indicates higher familiarity, lexical frequency and typicality for nonliving things. On the other hand, nonliving things also showed higher AoA and manipulability than living things. Finally, no category differences emerged for name agreement or visual complexity.

\section{Reliability and validity of the study}

To establish validity, we compared our stimuli with those of the classical $\mathrm{S} \& \mathrm{~V}$, plus a recent study which, like ours, was conducted with high quality colour images (Adlington et al., 2008). Pearson's correlations, including those items sharing the same name in the three studies ( $\mathrm{n}=41$ with $\mathrm{S} \& \mathrm{~V}$ and $\mathrm{n}=29$ with Adlington et al., 2008) are 
shown in Table 5. A high pattern of significant correlations (fluctuating between .59 and .89) was found among the different variables observed across the three studies. So, even where compared across English and Spanish, the ratings remain highly correlated. Regarding reliability, the Cronbach's Alpha coefficients were also high: $\alpha=.91$ (name agreement), $\alpha=.97$ (familiarity and manipulability) and $\alpha=.98$ (AoA, typicality and visual complexity).

Table 4. Psycholinguistic variables: Living-Nonliving differences.

\begin{tabular}{lcccccl}
\hline \multicolumn{7}{c}{ LT } \\
\hline & M & SD & M & SD & \multicolumn{1}{c}{$F$} & \multicolumn{1}{c}{$p$} \\
\hline AoA & 3.9 & 1.5 & 4.7 & 1.7 & 6.9 & $.01^{*}$ \\
Fam & 3.3 & 0.9 & 2.9 & 1.2 & 4.3 & $.04^{*}$ \\
LF & 15 & 1.5 & 14.1 & 2.9 & 5.8 & $.02^{*}$ \\
Man & 1.9 & 0.9 & 3.8 & 0.9 & 122.2 & $.0001^{*}$ \\
NA & 0.6 & 0.3 & 0.5 & 0.4 & 0.6 & .4 \\
Tip & 3.6 & 0.9 & 3.1 & 1.3 & 9.4 & $.003^{*}$ \\
VC & 2.6 & 0.6 & 2.8 & 0.8 & 1.9 & .2 \\
\hline
\end{tabular}

Note: $\mathrm{AoA}=$ Age of acquisision; Fam $=$ Familiarity, $\mathrm{LF}=$ Lexical frequency $(\log ) ;$ Man = Manipulability; NA = Name agreement Tip = Typicality $;$ VC = Visual complexity.

Table 5. Correlations between current stimuli and those of Adlington et al. (2009) and Snodgrass \& Vanderwart (1980).

\begin{tabular}{lcccccccc}
\hline & Items (n) & AoA & Fam & LF & Man & $\%$ NA & Tip & VC \\
\hline Adlington et al.'s & 29 & $.89^{*}$ & $.74^{*}$ & $.86^{*}$ & n.e. & $.67^{*}$ & n.e. & $.67^{*}$ \\
S\&V & 41 & $.78^{*}$ & $.66^{*}$ & $.65^{*}$ & n.e. & $.59^{*}$ & n.e. & $.74^{*}$ \\
\hline
\end{tabular}




\section{Discussion}

The main goal of the present research was to develop a new standardised corpus of colour photographs suitable for investigators to use in studies of language, memory, object processing and so on. This corpus has two main advantages compared to previous corpora: 1) items are sufficiently difficult to avoid ceiling effects when being named by healthy participants, 2) they have been standardised in several relevant variables, including some, such as manipulability, which are becoming more widely examined. Furthermore, the use of high quality colour photographs will not only increase ecological validity, but also facilitate experimental manipulation of perceptual properties.

Until now, many clinical and experimental studies of visual processing and object recognition have been carried out using the $S \& V$ (with over 1,700 citations in the past 10 years). Nevertheless, recent investigation has highlighted several limitations of the aforementioned corpus. One of the more relevant, especially when comparing the performance of a clinical population with that of healthy controls, is the presence of ceiling effects in the $\mathrm{S} \& \mathrm{~V}$ items. Under normal viewing conditions, the majority of the items from the $S \& V$ can be readily named by the vast majority of healthy participants and so produces ceiling effects that can distort the degree and, even, the nature of a deficit reported in neurological patients (Laws, 2005; Laws et al., 2005). This problem is compounded when data are analysed using standard parametric techniques, such as a $t$ test or ANOVA, which may not be suitable for such data (see Erceg-Hurn \& Mirosevich, 2008; Moreno-Martínez \& Laws, 2007, 2008). In contrast, our stimuli more satisfactorily deal with this methodological problem, since mean naming performance in our healthy sample was below ceiling (see Table 4). 
Another advantage of our stimuli is the availability of norms for both AoA and manipulability. These relevant variables are starting to be more widely studied. For example, recent work underscores the importance of the relationship between item manipulability (i.e. the degree the use of the human hand is necessary for the object performs its function) and its semantic representation (e.g., Allport, 1985; Buxbaum \& Saffran, 2002; Magnié et al., 2003; Tranel et al., 1997; Warrington \& McCarthy, 1987). For example, differences in manipulability could produce significant differences in object identification, both in clinical (Warrington \& McCarthy, 1987) and in healthy participants (Filliter, McMullen, \& Westwood, 2005; McMullen \& Purdy, 2006).

As with other normative studies, the standard psycholinguistic variables tend to correlate with each other (see Adlington et al., 2008; Sanfeliú \& Fernández, 1996; Snodgrass \& Vanderwart, 1980). By contrast, manipulability failed to correlate with either naming percentage or the $H$ index; and indeed, correlated only with lexical frequency. The reason for a lack of relation between manipulability and naming, whilst contrary to previous findings (Filliter et al., 2005; McMullen \& Purdy, 2006), is unclear. We suggest that the influence of manipulability on naming may be only relevant for those subcategories that drastically differ in terms of manipulability, e.g. birds versus land vehicles (non-manipulable and manipulable objects, respectively; see Filliter et al., 2005; McMullen \& Purdy, 2006). In any case, a complete set of items which an empirically-derived set of manipulability index could be particularly useful to this field, mainly when only a few studies have presented ratings of objective manipulability (Magnié et al., 2003; Moreno-Martínez \& Peraita, 2007). This is particularly relevant because the role of manipulability has mainly been studied using an apriori approximation to this term, i.e. using objects that theoretically differ in 
manipulability (Filliter et al., 2005; McMullen \& Purdy, 2006, although see Magnié et al., 2003).

Obviously, an evident difference between drawings from $\mathrm{S} \& \mathrm{~V}$ and our photographs is the presence of colour in the latter. The role of colour for object recognition is, at present, a matter of controversy. Whilst some studies have supported that colour is highly relevant to identifying objects (Laws \& Hunter, 2006), others seem to report the contrary (Biederman \& Ju, 1988). For example, a meta-analytic review by Laws, Adlington, Gale, Moreno-Martínez, and Sartori (2007) reported that the addition of colour may not benefit (and may even worsen) object recognition in people with Alzheimer's disease. This seems to run contrary to the idea that the recognition performance of agnosics benefits from colour information (Mapelli \& Behrmann, 1997). Consequently, the use of stimuli susceptible to be easily modifiable attributes will permit further investigation on this relevant area. Indeed, researchers have recently showed a progressive tendency to focus on the role of colour in object recognition (Adlington et al., 2009; Zannino et al., 2010), with coloured stimuli becoming increasingly developed over the past few years (Adlington et al., 2008; MorenoMartínez \& Peraita, 2007; Rossion \& Pourtois, 2004; Viggiano, et al., 2004).

Analysis of reliability and validity shows that our items present comparable characteristics with those of other similar studies and that our scales have a high internal consistency as well. Furthermore, the item analysis list provided will let the authors to select the more suitable items according to their goals. To conclude, the set of items presented in this work provide a useful tool for researchers examining in language, 
memory and object processing, particularly for authors interested in comparing healthy versus neurologically damaged performance. 


\section{References}

Adlington, R.L., Laws, K.R., \& Gale, T.M. (2008). The Hatfield Image Test (HIT): A new picture test and norms for experimental and clinical use. Journal of Clinical \& Experimental Neuropsychology, 31, 731-753.

Adlington, R.L., Laws, K.R., \& Gale, T.M. (2009). Visual processing in Alzheimer's disease: Surface detail and colour fail to aid object identification. Neuropsychologia, 47, 2574-2583.

Altavista.com, (April 2008). Available: http://www.altavista.com

Allport, D.A. (1985). Distributed memory, modular subsystems and dysphasia. In: Newman SK, Epstein R, editors. Current Perspectives in Dysphasia. Edinburgh (pp. 32-60): Churchill Livingstone.

Baayen, R. H., Piepenbrock. R., \& Gulikers, L. (1995). The CELEX lexical database. Philadelphia: University of Pennsylvania, Linguistic Data Consortium.

Barbarotto, R., Capitani, E., \& Laiacona, M. (2001). Living musical instruments and inanimate body parts? Neuropsychologia, 39, 406-414.

Beauchamp, M. S., Lee, K. E., Haxby, J. V., \& Martin, A. (2002). Parallel visual motion processing streams for manipulable objects and human movements. Neuron, $34,149-159$.

Beauchamp, M. S., Lee, K. E., Haxby, J. V., \& Martin, A. (2003). FMRI responses to video and point-light displays of moving humans and manipulable objects. Journal of Cognitive Neuroscience, 15, 991-1001.

Biederman, I., \& Ju, G. (1988). Surface versus edge-based determinants of visual recognition. Cognitive Psychology, 20, 38-64. 
Blair, I. V., Urland, G.R., \& Ma, J. E. (2002). Using internet search engines to estimate word frequency. Behavior Research Methods, Instruments, \& Computers, 34, 286290.

Brodeur, M.B., Dionne-Dostie, E., Montreuil, T., \& Lepage, M. (2010). The BOSS, a new set of 538 normalized photos of objects to be used as ecological stimuli in vision and memory paradigms. PLoS ONE, 5, e10773

Buxbaum, L.J., \& Saffran, E.M. (2002). Knowledge of object manipulation and object function: Dissociations in apraxic and nonapraxic subjects. Brain \& Language, 82. 179-199.

Capitani, E., Laiacona, M., Mahon, B., \& Caramazza, A. (2003). What are the facts of semantic category-specific deficits? A critical review of the clinical evidence. Cognitive Neuropsychology, 20, 213-261.

Caramazza, A., \& Shelton, J.R. (1998). Domain-specific knowledge systems in the brain: the animate-inanimate distinction. Journal of Cognitive Neuroscience, 10, 134.

Erceg-Hurn, D.V., \& Mirosevich, V.M. (2008). Modern robust statistical methods. American Psychologist, 7, 591-601.

Filliter, J.H., McMullen, P.A., \& Westwood, D. (2005). Manipulability and living/nonliving category effects on object identification. Brain \& Cognition, 57, 61-65.

Gilhooly, K. J., \& Gilhooly, M.L.M. (1979). Age-of-acquisition effects in lexical and episodic memory tasks. Memory \& Cognition, 7, 214-223.

Holmes, S., Fitch, F.J., \& Ellis, A. (2006). Age of Acquisition affects object recognition and naming in patients with Alzheimer's disease. Journal of Clinical and Experimental Neuropsychology, 28, 1010-1022. 
Kellenbach, M., Brett, M.,\&Patterson, K. (2003). Actions speak louder than functions: The importance of manipulability and action in tool representation. Journal of Cognitive Neuroscience, 15, 30-46.

Kucera, H., \& Francis, W. (1967). Computational analysis of present-day American English Providence. Rhode Island: Brown University Press.

Laws, K.R. (2005). Illusions of normality: A methodological critique of categoryspecific naming. Cortex, 41, 842-851.

Laws, K. R., Adlington, R. L., Gale, T. M., Moreno-Martínez, F. J., \& Sartori, G. (2007). A meta-analytic review of category naming in Alzheimer's disease. Neuropsychologia, 45, 2674-2682.

Laws, K. R., Gale, T. M., Frank, R., \& Davey, N. (2002). Visual similarity is greater for line drawings of non-living than living things: the importance of musical instruments and body parts. Brain \& Cognition, 48, 421-424.

Laws, K.R., Gale, T.M., Leeson, V.C., \& Crawford, J.R. (2005). When is category specific in Alzheimer's disease? Cortex, 41, 1-12.

Laws, K. R., \& Hunter, M. Z. (2006). The impact of colour, spatial resolution, presentation speed on category naming. Brain \& Cognition, 62, 89-97.

Magnié, M.N., Besson, M., Poncet, M., \& Dolisi, C. (2003) The Snodgrass and Vanderwart set revisited: Norms for object manipulability and for pictorial ambiguity of objects, chimeric objects and nonobjects. Journal of Clinical \& Experimental Neuropsychology, 25, 521-560.

Mapelli, D., \& Behrmann, M. (1997). The role of colour in object recognition: evidence from visual agnosia. Neurocase, 3, 237-247.

Martin, A. (2007). The representation of object concepts in the brain. Annual Review of Psychology, 58, 25-45. 
McMullen, P.A., \& Purdy, K.S. (2006). Category-specific effects on the identification of non-manipulable objects. Brain \& Cognition, 62, 228-240.

Moreno-Martínez, F.J., \& Laws, K.R. (2007). An attenuation of the 'normal' category effect in patients with Alzheimer's disease: a review and bootstrap analysis. Brain \& Cognition, 63, 167-173.

Moreno-Martínez, F.J., \& Laws, K.R. (2008). No category-specificity in Alzheimer's disease: A normal aging effect. Neuropsychology, 22, 485-490.

Moreno-Martínez, F.J., Laws, K.R., \& Schultz, J. (2008). The impact of dementia, age and sex on category fluency: Greater deficits in women with Alzheimer's disease. Cortex, 44, 1256-1264.

Moreno-Martínez, F.J., \& Peraita, H. (2007). Un nuevo conjunto de ítems para la evaluación de la disociación ser vivo / ser no vivo con normas obtenidas de ancianos sanos españoles [A new set of items for the evaluation of living/nonliving dissociations with norms collected from healthy elderly Spanish]. Psicológica, 28, 120.

Oliva, A., \& Schyns, P. (2000). Diagnostic colors mediate scene recognition. Cognitive Psychology, 41, 176-210.

Pompéia S., Miranda M.C., Bueno, O.F. (2003) Brazilian standardised norms for a set of pictures are comparable with those obtained internationally. Arquivos de NeuroPsiquiatria 61, 916-919.

Price, C. J., \& Humphreys, G.W. (1989). The effects of surface detail on object categorization and naming. Quarterly Journal of Experimental Psychology A, Human Experimental Psychology, 41, 797-827. 
Rossion, B., \& Pourtois, G. (2004). Revisiting Snodgrass and Vanderwart's object pictorial set: the role of surface detail in basic-level object recognition. Perception, $33,217-236$.

Sanfeliú M.C., \& Fernández, A. (1996). A set of 254 Snodgrass-Vanderwart's pictures standardized for Spanish: Norms for name agreement, image agreement, familiarity and visual complexity. Behavior Research Methods, Instruments \& Computers, 28, $537-555$.

Sebastián N., Martí, M.A., Carreiras, M.F., \& Cuetos, F. (2000). LEXESP, Léxico informatizado del Español. Barcelona: Ediciones de la Universitat de Barcelona.

Silveri, M.C., Cappa, A., Mariotti, P., \& Puopolo, M. (2002). Naming in patients with Alzheimer's disease: Influence of age of acquisition and categorical effects. Journal of Clinical and Experimental Neuropsychology, 24, 755-764.

Snodgrass, J.G., \& Vanderwart, M. (1980). A Standardized Set of 260 Pictures: Norms for Name Agreement, Image Agreement, Familiarity, and Visual Complexity. Journal of Experimental Psychology: Human Learning \& Memory, 6, 174-215.

Tanaka, J. W., \& Presnell, L. M. (1999). Colour diagnosticity in object recognition. Perception and Psychophysics, 61, 1140-1153.

Tranel, D., Logan, C.G., Randall, J.F., \& Damasio, A.R. (1997). Explaining categoryrelated effects in the retrieval of conceptual and lexical knowledge for concrete entities: operationalization and analysis of factors. Neuropsychologia, 35, 13291339.

Viggiano, M.P., Vannucci, M., \& Righi, S. (2004). A new standardized set of ecological pictures for experimental and clinical research on visual object processing. Cortex, 40, 494-509. 
Warrington, E.K., \& McCarthy, R.A. (1987). Categories of knowledge: Further fractionations and an attempted integration. Brain, 110, 1273-1296.

Wurm, L.H., Legge, G.E., Isenberg, L.M., \& Luebker, A. (1993). Color improves object recognition in normal and low vision. Journal of Experimental Psychology: Human Perception and Performance, 19, 899-911.

Zannino GD, Perri R, Salamone G, Di Lorenzo C, Caltagirone C, Carlesimo GA. (2010). Manipulating color and other visual information influences picture naming at different levels of processing: evidence from Alzheimer subjects and normal controls. Neuropsychologia, 48, 2571-2578. 


\section{Authors note}

F. Javier Moreno-Martínez and Pedro R. Montoro, Departamento de Psicología Básica I, U.N.E.D. Madrid, Spain;

Keith R Laws, School of Psychology, University of Hertfordshire, UK.

\section{Acknowledgments}

We wish to thank Sara Cañamón for her help selecting and taking photographs of the items. We would like to thank the anonymous reviewers for their very helpful comments on an earlier draft of this paper.

\section{Address for correspondence:}

F. Javier Moreno-Martínez

U.N.E.D.

Departamento de Psicología Básica I

C/ Juan del Rosal, nº 10, 28040-Madrid. Spain.

Telephone: 91-398-88-53; Fax: 91-398-79-72.

E-mail: fjmoreno@psi.uned.es 
Appendix A. Normative psycholinguistic ratings for each item

\begin{tabular}{|c|c|c|c|c|c|c|c|c|c|c|c|c|c|c|}
\hline \multicolumn{2}{|c|}{ Item } & \multicolumn{2}{|c|}{ AoA } & \multicolumn{2}{|c|}{ Fam } & \multicolumn{2}{|c|}{ Man } & \multicolumn{2}{|c|}{ Typical } & \multicolumn{2}{|c|}{ VC } & \multirow[b]{2}{*}{$\mathbf{p}$} & \multirow[b]{2}{*}{$\boldsymbol{H}$} & \multirow{2}{*}{$\frac{\mathbf{L F}}{\text { Lo }}$} \\
\hline English & Spanish & $M$ & $S$ & $M$ & $S$ & $M$ & $S$ & $M$ & $S$ & $M$ & $S$ & & & \\
\hline \multicolumn{15}{|l|}{ ANIMAL } \\
\hline Cat & Gato & 1. & 0. & 4. & 0. & 1. & 1. & 4. & 0. & 3. & 1. & 1 & 0 & 17. \\
\hline Cow & Vaca & 1. & 0. & 4. & 1. & 2. & 1. & 4. & 0. & 2. & 1. & 1 & 0 & 16. \\
\hline Elephant & Elefante & 2. & 0. & 3. & 1. & 1. & 0. & 4. & 0. & 2. & 1. & 1 & 0 & 15. \\
\hline Genet & Jineta & 6. & 1. & 1. & 0. & 1. & 0. & 1. & 1. & 3. & 1 & 0. & 2. & 11. \\
\hline Hen & Gallina & 2. & 0. & 4. & 1. & 1. & 1. & 4. & 0. & 3. & 1. & 0. & 0. & 16. \\
\hline Kangaroo & Canguro & 3. & 1. & 2. & 1. & 1. & 0. & 3. & 1. & 2. & 1. & 0. & 0 & 15. \\
\hline Kiwi & Kiwi & 6. & 1. & 1. & 0. & 1. & 0. & 1. & 0. & 3. & 1. & 0. & 2. & 15 . \\
\hline Ray & Raya & 5. & 1. & 1. & 0. & 1. & 0. & 1. & 1. & 2. & 1. & 0. & 1. & 15. \\
\hline Rhino & Rinoceront & 3. & 1. & 2. & 1. & 1. & 0. & 3. & 1. & 3. & 1. & 0. & 0. & 13. \\
\hline Tapir & Tapir & 6. & 0. & 1. & 0. & 1. & 0. & 1. & 1. & 3. & 0. & 0 . & 2. & 12. \\
\hline \multicolumn{15}{|l|}{$B O D Y$} \\
\hline Cerebelum & Cerebelo & 6. & 0. & 2. & 1. & 1. & 0. & 2. & 1. & 4. & 0. & 0. & 2. & 13. \\
\hline Foot & Pie & 1. & 0. & 4. & 0. & 1. & 0. & 4. & 0. & 2. & 1. & 1 & 0 & 18. \\
\hline Hand & Mano & 1. & 0. & 4. & 0. & 3. & 1. & 4. & 0. & 2. & 1. & 0. & 0. & 19. \\
\hline Kidney & Riñón & 4. & 1. & 2. & 1. & 1. & 0. & 3. & 1. & 1. & 1. & 0. & 1. & 15. \\
\hline Leg & Pierna & 1. & 0. & 4. & 0. & 1. & 0. & 4. & 0. & 1. & 0. & 0. & 0 . & 16. \\
\hline Liver & Hígado & 4. & 1. & 2. & 1. & 1. & 0. & 3. & 1. & 2. & 1. & 0. & 1. & 16. \\
\hline Lung & Pulmón & 4. & 1. & 2. & 1. & 1. & 0. & 3. & 1. & 2. & 1. & 0. & 2. & 16. \\
\hline Pelvis & Pelvis & 5. & 1. & 2. & 1. & 1. & 0. & 2. & 1. & 3. & 1. & 0. & 1. & 14. \\
\hline Skull & Cráneo & 4. & 1. & 3. & 1. & 1. & 0. & 3. & 1. & 3. & 1. & 0. & 1. & 15. \\
\hline Vertebra & Vértebra & 5. & 1. & 2. & 1. & 1. & 0. & 2. & 1. & 3. & 1. & 0 . & 1. & 13. \\
\hline \multicolumn{15}{|l|}{ FLOWER } \\
\hline Araceae & Cala & 6. & 1. & 2. & 1. & 1. & 0. & 2. & 1. & 2. & 0. & 0. & 2. & 16. \\
\hline Bellflower & Campanill & 5. & 1. & 2. & 1. & 1. & 0. & 2. & 1. & 2. & 0. & 0 . & 2. & 14. \\
\hline Carnation & Clavel & 3. & 1. & 3. & 1. & 1. & 1. & 4. & 0. & 2. & 1. & 0 . & 0. & 14. \\
\hline Daisy & Margarita & 2. & 0. & 4. & 0. & 1. & 1. & 4. & 0. & 2. & 1. & 0. & 0. & 17. \\
\hline Geranium & Geranio & 4. & 1. & 3. & 1. & 1. & 1. & 3. & 1. & 3. & 0. & 0. & 2. & 13. \\
\hline Orchid & Orquídea & 5. & 1. & 2. & 1. & 1. & 1. & 3. & 1. & 3. & 1. & 0 . & 1. & 14. \\
\hline Pansy & Pensamien & 5. & 1. & 2. & 1. & 1. & 1. & 2. & 1. & 3. & 1. & 0 . & 1. & 18. \\
\hline Poppy & Amapola & 3. & 1. & 3. & 1. & 1. & 0. & 4. & 0. & 2. & 1. & 0. & 0 . & 14. \\
\hline Rose & Rosa & 2. & 1. & 4. & 0. & 1. & 1. & 4. & 0. & 3. & 1. & 0. & 0. & 18. \\
\hline Tulip & Tulipán & 4. & 1. & 3. & 1. & 1. & 1. & 3. & 0. & 2. & 0. & 0 . & 1. & 13. \\
\hline \multicolumn{15}{|l|}{ FRUITS } \\
\hline Blueberry & Arándanos & 6. & 1. & 1. & 0. & 2. & 1. & 2. & 1. & 2. & 1. & 0. & 2. & 13. \\
\hline Medlar & Níspero & 5. & 1. & 2. & 1. & 3. & 1. & 2. & 1. & 1. & 0. & 0 . & 2. & 12. \\
\hline Melon & Melón & 2. & 0. & 4. & 0. & 3. & 1. & 4. & 0. & 1. & 0. & 0. & 0. & 15 . \\
\hline Papaya & Papaya & 6. & 1. & 2. & 1. & 3. & 1. & 2. & 1. & 1. & 1. & 0 . & 2. & 14. \\
\hline Peach & Melocotón & 2. & 0. & 4. & 0. & 3. & 1. & 4. & 0 . & 1. & 0. & 0. & 0 . & 14. \\
\hline Pear & Pera & 2 & 0. & 4. & 0. & 3. & 1. & 4. & 0 . & 1. & 0. & 0. & 0 & 15. \\
\hline Quince & Membrillo & 4. & 1. & 2. & 1. & 3. & 1. & 2. & 1. & 1. & 1. & 0. & 2. & 14. \\
\hline Redcurrant & Grosellas & 6. & 1. & 1. & 0. & 2. & 1. & 1. & 1. & 3. & 0. & 0. & 2. & 12. \\
\hline Strawberry & Fresa & 2. & 0. & 4. & 0. & 3. & 1. & 4. & 0. & 2 & 0. & 0. & 0 . & 15. \\
\hline Watermelo & Sandía & 2. & 0. & 4. & 0. & 3. & 1. & 4. & 0. & 1. & 0. & 0. & 0. & 14. \\
\hline
\end{tabular}


$\begin{array}{llllllllllllllll}\text { Ant } & \text { Hormiga } & 2 & 0 . & 4 . & 0 . & 1 . & 0 . & 4 . & 0 . & 2 . & 1 . & 0 . & 0 . & 15 .\end{array}$

$\begin{array}{llllllllllllll}\text { Bee } & \text { Abeja } & 2 . & 0 . & 3 . & 1 . & 1 . & 0 . & 4 . & 0 . & 3 . & 1 . & 0 . & 1 .\end{array}$.

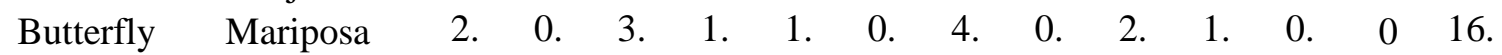

$\begin{array}{llllllllllllll}\text { Cockroach Cucaracha } & 3 . & 0 . & 3 . & 1 . & 1 . & 0 . & 4 . & 0 . & 2 . & 1 . & 0 . & 1 . & 14 .\end{array}$

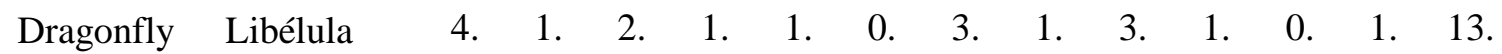

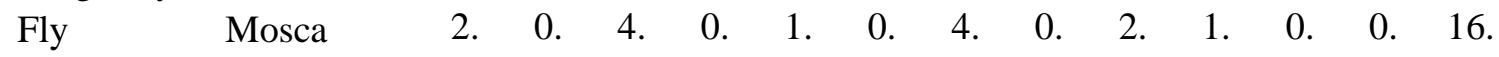

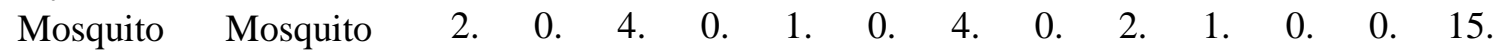

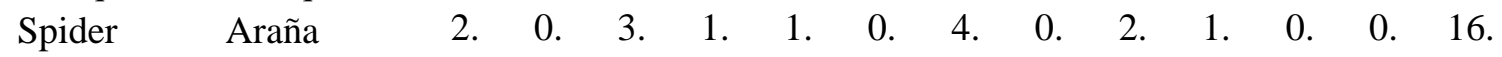

$\begin{array}{lllllllllllllll}\text { Termite } & \text { Termita } & 5 . & 1 . & 1 . & 1 & 1 . & 0 . & 2 . & 1 . & 3 . & 1 . & 0 . & 2 . & 12 .\end{array}$

$\begin{array}{llllllllllllll}\text { Wasp } & \text { Avispa } & 2 . & 0 . & 3 . & 1 . & 1 . & 0 . & 4 . & 0 . & 3 . & 1 . & 0 . & 0 .\end{array}$

\section{TREES}

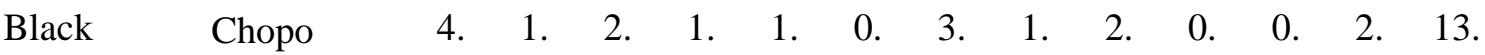

$\begin{array}{lllllllllllllll}\text { Cedar } & \text { Cedro } & 5 . & 1 . & 2 . & 1 . & 1 . & 0 . & 2 . & 1 . & 2 . & 1 . & 0 . & 1 . & 14 .\end{array}$

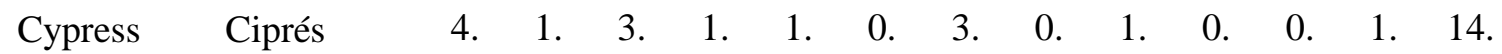

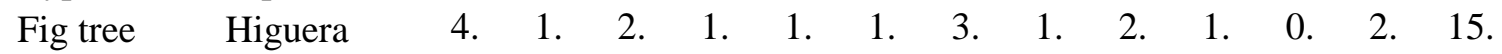

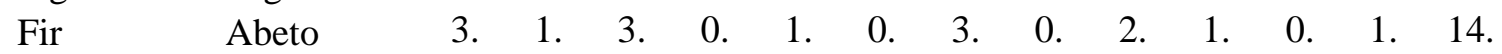

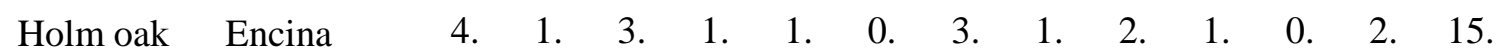

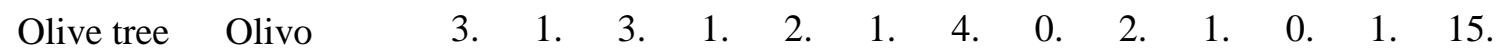

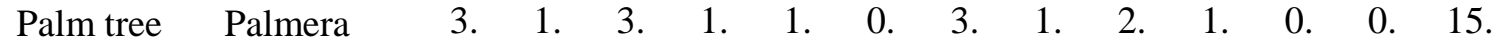

$\begin{array}{llllllllllllll}\text { Pine tree } & \text { Pino } & 3 & 1 . & 3 . & 1 . & 1 . & 0 . & 4 . & 0 . & 2 . & 0 . & 0 . & 1 .\end{array}$

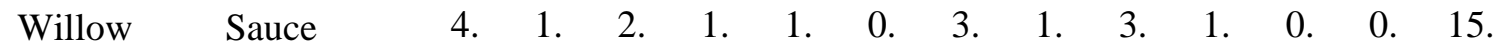

VEGETA

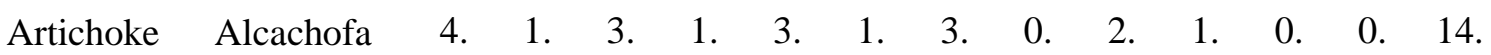

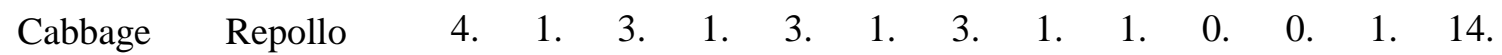

$\begin{array}{llllllllllllll}\text { Cauliflowe Coliflor } & 3 . & 1 . & 3 . & 1 . & 3 . & 1 . & 4 . & 0 . & 2 . & 1 . & 0 . & 0 . & 14 .\end{array}$

$\begin{array}{lllllllllllllll}\text { Celery Apio } & 5 . & 1 . & 3 . & 1 . & 3 . & 1 . & 3 . & 1 . & 2 . & 0 . & 0 . & 2 . & 14 .\end{array}$

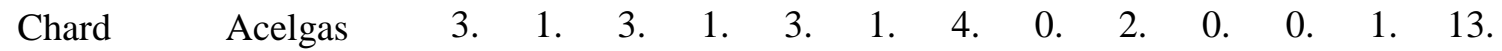

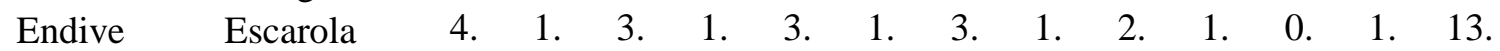

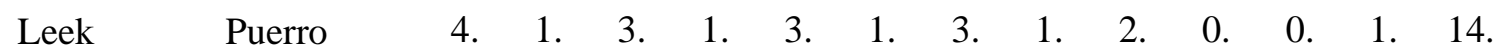

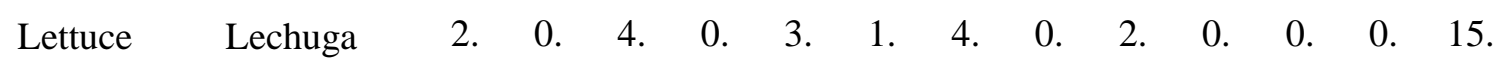

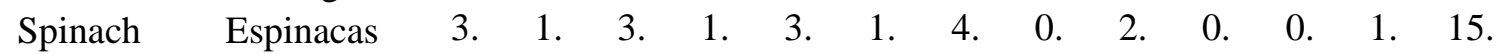

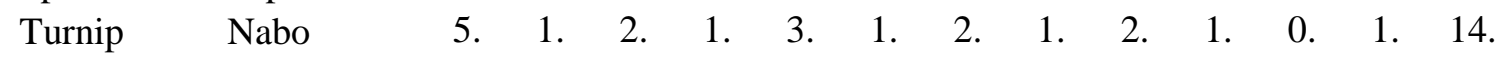

\section{BUILDIN}

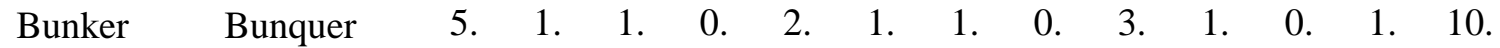

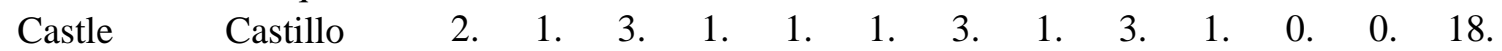

$\begin{array}{llllllllllllll}\text { House } & \text { Casa } & 1 . & 0 . & 4 . & 0 . & 2 . & 1 . & 4 . & 0 . & 2 . & 1 . & 0 . & 0 .\end{array}$

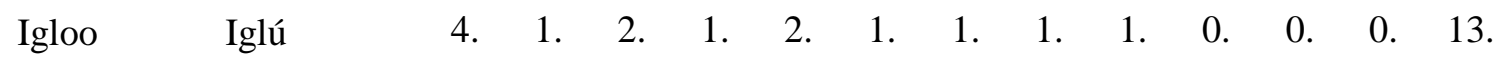

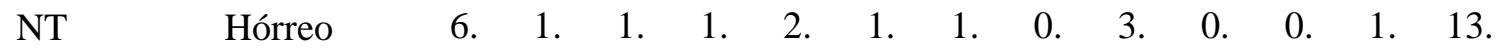

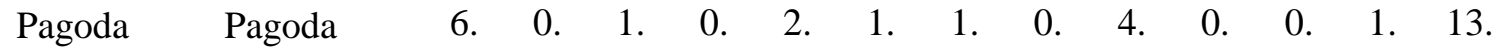

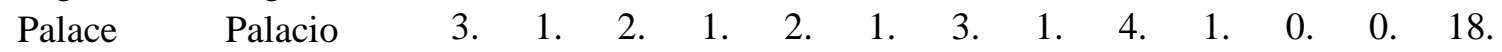

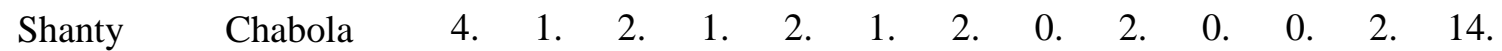

$\begin{array}{llllllllllllll}\text { Silo Silo } & 6 . & 1 . & 1 . & 0 . & 2 . & 1 . & 1 . & 0 . & 2 . & 1 . & 0 . & 2 & 14 .\end{array}$

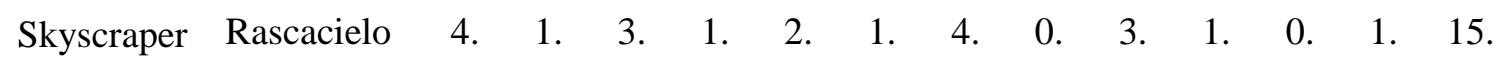

\section{CLOTHI}

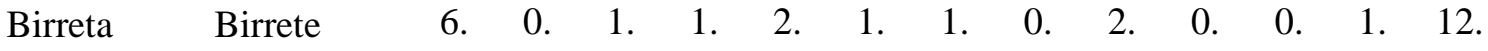

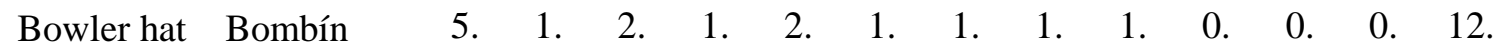

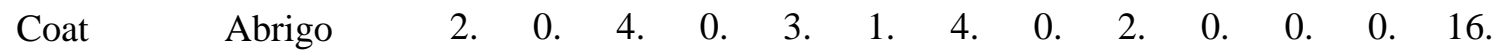

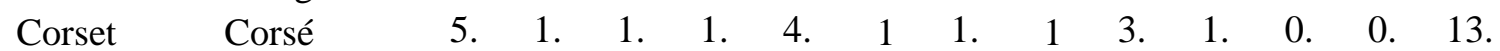

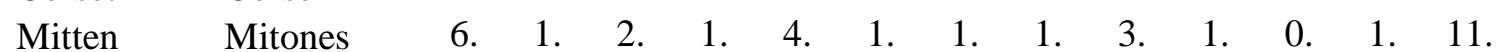




\begin{tabular}{|c|c|c|c|c|c|c|c|c|c|c|c|c|c|c|}
\hline lood & Muceta & 6 & 0 . & 1. & 0. & 2. & 1. & 1. & 0. & 2 & 1. & 0. & & 10 \\
\hline Kimono & Quimono & & 1. & 2. & 1. & 5 . & 1. & 2. & 1 & 3. & 0. & 0. & & \\
\hline NT & Pololos & 5. & 1. & 1. & 0. & 3. & 1. & 1. & 1. & 1. & 0. & . & & \\
\hline Skirt & alda & & 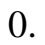 & 4. & 0. & 2 & 1. & 4 & 0. & 1. & 0. & 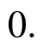 & & \\
\hline Socks & alcetines & & 0 & 4. & 0. & & 1. & 4. & 0. & 1. & 0. & 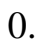 & & \\
\hline \multicolumn{15}{|l|}{ FURNIT } \\
\hline Bed & ama & 1. & 0 . & 4. & 0. & 2. & 1. & 4. & 0. & 2. & 1. & 0. & & \\
\hline Bedside & Mesilla & 3. & 1. & 4. & 0. & $p$. & 1. & 4. & 0. & 2. & 0. & 0. & 1. & \\
\hline Bookcase & Librería & . & 1. & 4. & 0. & 3. & 1. & 4. & 0. & 3. & 1. & 0. & & \\
\hline Bureau & Bargueño & . & 0 . & 1. & 0. & 2. & 1. & 1. & 0. & 4. & 0. & 0. & & \\
\hline Chest of & Cómoda & 4. & 1. & 3. & 1. & 3. & 1. & 3. & 1. & 2. & 0. & 0. & & \\
\hline Couch & Diván & 5 & 1. & 2. & 1. & 1. & 1. & 2. & 1. & 3. & 0. & 0. & & \\
\hline Filing & Archivado & J. & 1. & 3. & 1. & 3. & 1. & 2. & 1. & 2. & 0. & ). & & \\
\hline Magazine & Revistero & 5. & 1. & 3. & 1. & 2. & 1. & 2. & 1. & 3. & 1. & . & . & \\
\hline Sideboard & Aparador & 5. & 1. & 3. & 1. & 3. & 1. & 3. & 1. & 2. & 0. & 0. & & \\
\hline Sofa & Sofá & r. & 1. & 4. & 0. & 1. & 1. & 4. & 0. & 2. & 0. & . & & \\
\hline \multicolumn{15}{|l|}{ KITCHE } \\
\hline Chinese & Chino & 5. & 1. & 2. & 1. & 4. & 0. & 2. & 1. & 2. & 0. & 0. & 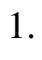 & \\
\hline Cooking & Puchero & 4. & 1. & 2. & 1. & 3. & 1. & 2. & 1. & 2. & 0. & 0. & & \\
\hline Fondue & Fondue & . & 0. & 2. & 1. & 4. & 0. & 1. & 1. & 3. & 1. & 0. & ). & \\
\hline ruit corer & Descora & & 0 . & 1. & 0. & 4. & 0. & 1. & 1. & 2. & 0. & 0. & . & \\
\hline Frying pan & Sartén & 2. & 0 . & 4. & 0. & 4. & 0. & 4. & 0. & 1. & 0. & 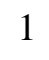 & 0 & \\
\hline NT & Churrera & 5. & 1. & 1. & 0. & 4. & 0. & 1. & 0. & 3. & 0. & 0. & 1 . & \\
\hline Peeler & Pelador & & 1. & 2. & 1. & 4. & 0. & 2. & 1. & 2. & 0. & 0. & . & \\
\hline Pot & Olla & 3. & 1. & 4. & 0. & 4. & 1. & 4. & 0. & 2. & 0. & ). & 1. & \\
\hline Sauc & Cazo & & 0 . & 4. & 0. & 4. & 1. & 4. & 0. & 1. & 0. & • & . & \\
\hline Sharpenin & Chaira & o. & 0. & 1. & 1. & 4. & 0. & 1. & 0. & 1. & 0. & 0. & 2. & \\
\hline \multicolumn{15}{|l|}{ MUSICA } \\
\hline Balalaika & aica & 6. & 0 . & 1. & 0. & 4. & 0. & 1. & 1. & 3. & 0. & 0. & 2. & \\
\hline Clarinet & $\mathrm{Cla}$ & & 1. & 2. & 1. & 4. & 0. & 3. & 1. & 3. & 1. & 0. & 1. & \\
\hline Clavichord & Clavicordi & & 0 . & 1. & 0. & 4. & 0. & 2 & 1. & 4. & 0. & 0. & 2. & \\
\hline Flute & Flauta & 2. & 0. & 3. & 1. & 4. & 0. & 4. & 0. & 1. & 0. & 1 & 0 & \\
\hline Harp & Arpa & 4. & 1. & 2. & 1. & 4. & 0. & 3. & 1. & 3. & 1. & 0. & 0. & \\
\hline Piano & Piar & 3 & 1. & 3. & 1. & 4. & 0. & 4. & 0. & 4. & 1. & & 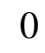 & \\
\hline Saxophone & Saxofón & 4. & 1. & 2. & 1. & 4. & 0. & 3. & 0. & 4. & 0. & 0. & 0 . & \\
\hline Trumpet & Tromp & & 1. & 3. & 1. & 4. & 0. & 4. & 0. & 3. & 1. & ). & 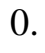 & \\
\hline Tuba & Tuba & & 1. & 1. & 0. & 4. & 0. & 2. & 1. & 3. & 1. & 0. & . & \\
\hline Violin & Violín & 3. & 1. & 3. & 1. & 4. & 0. & 4. & 0. & 3. & 1. & 0 . & 0. & \\
\hline \multicolumn{15}{|l|}{ TOOLS } \\
\hline Bent & Gubia & 6. & 0 . & 1. & 0. & 4. & 0. & 1. & 1. & 2. & 1 & 0. & 2. & \\
\hline Chisel & Formon & 6 & 1. & 1. & 1. & 4. & 0. & 2. & 1. & 2. & 0. & 0. & 2. & \\
\hline Cold & Cortafríos & 6. & 1. & 2. & 1. & 4. & 1. & 2. & 1. & 1. & 1. & 0. & 2. & \\
\hline Handsaw & Serrucho & 3. & 1. & 3. & 1. & 4. & 0. & 4. & 0. & 1. & 0. & 0. & 0. & \\
\hline Pick-axe & Alcotana & 6. & 1. & 1. & 1. & 4. & 0. & 2. & 1. & 1. & 0. & 0. & 2. & \\
\hline Pincers & Alicates & 4. & 1. & 3. & 0. & 4. & 0. & 4. & 0. & 2. & 0. & 0. & 0. & \\
\hline Pliers & Tenazas & 4. & 1. & 3. & 1. & 4. & 0. & 4. & 0. & 1. & 0. & 0. & 0 . & \\
\hline Screwdriv & Destornilla & 3. & 1. & 4. & .9 & 4. & 0. & 4. & 0. & 1. & 0. & 0. & 0 . & \\
\hline Shovel & Pala & ᄀ & 1. & 3. & 1. & 4. & 0. & 4. & 0. & 1. & 0. & 0. & 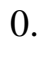 & \\
\hline Trowel & Llana & 5. & 1. & 2. & 1. & 4. & 0. & 2. & 1. & 2. & 0. & 0. & 2. & \\
\hline
\end{tabular}




\begin{tabular}{|c|c|c|c|c|c|c|c|c|c|c|c|c|c|}
\hline elvis & elvis & 5.5 & 5.9 & 2.7 & 2.3 & 1.3 & 1.1 & 2.7 & 2.6 & 3.2 & 3.2 & 0.3 & 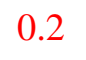 \\
\hline Skull & ráneo & 4.4 & 4.2 & 3.5 & 3.0 & 1.2 & 1.3 & 3.8 & 3.6 & 3.3 & 3.4 & 0.4 & 0.4 \\
\hline Vertebra & értebra & 5 & .5 & 2.8 & 2.4 & 1.1 & 1.4 & 2.7 & 2.6 & 3 & 0 & 0.3 & 4 \\
\hline \multicolumn{14}{|l|}{ FLOWERS } \\
\hline Araceae & ala & 1 & .2 & 3 & .1 & 1.5 & 1.6 & 2.2 & 2.4 & 0 & 0 & .1 & \\
\hline Bellflowers & ampanilla & 3 & 5 & 2 & .2 & 1.5 & 1.4 & 2.5 & 2.7 & .9 & .9 & .0 & \\
\hline Carnation & Clavel & .5 & 3.5 & 4 & .8 & 1.9 & 1.8 & 4.5 & 4.6 & 2.7 & .9 & 0.8 & \\
\hline Daisy & Iargarita & 5 & .5 & 4.2 & .3 & 1.7 & 1.7 & 4.8 & 4.8 & .0 & .2 & 0.9 & .5 \\
\hline Geranium & Ieranio & 5 & 4.2 & 3.3 & .1 & 1.8 & 1.8 & 3.7 & 3.9 & 3.9 & .8 & .0 & 0.1 \\
\hline Orchid & rquî & & 6.0 & 2.6 & .4 & 1.5 & 1.7 & 3.4 & 3.3 & .4 & .4 & 0.1 & \\
\hline Pansy & Pensamient & & .7 & .1 & 3 & 1.6 & 1.6 & 2.3 & 2.9 & .2 & .4 & 0.1 & \\
\hline Poppy & mapola & 3 & 3.3 & .5 & 3.6 & 1.6 & 1.4 & 4.1 & 4.2 & .5 & .5 & 0.7 & 1.8 \\
\hline Rose & osa & 5 & 2.6 & .4 & .3 & 1.9 & 1.9 & 4.8 & 4.9 & .0 & 1 & 0.9 & 0.9 \\
\hline Tulip & án & & .3 & .1 & & 1.5 & 1.7 & 4 & .8 & & & 5 & \\
\hline \multicolumn{14}{|l|}{ FRUITS } \\
\hline Blueberry & rán & & 6.2 & 9 & 9 & 3.0 & 2.7 & 2.0 & 2.0 & .2 & .2 & 0 & 0.1 \\
\hline Iedlar & ísp & & .1 & .2 & .8 & 3.5 & 3.4 & 2.2 & 2.7 & .4 & .5 & 0.1 & \\
\hline Melon & Ielón & 5 & 2.3 & .4 & 6 & 3.6 & 3.1 & 4.4 & 4.2 & .5 & .6 & 1 & \\
\hline apaya & apava & & 6.3 & 9 & .0 & 3.5 & 3.4 & 2.2 & 2.2 & .8 & .9 & 0.0 & \\
\hline each & el & & 2.5 & .4 & 4 & 3.5 & 3.4 & 4.5 & 4.6 & .3 & .3 & 0.7 & 0 . \\
\hline Pear & era & 2.0 & 1.9 & 4.7 & 4.7 & 3.5 & 3.4 & 4.8 & 4.9 & .5 & .6 & 1 & \\
\hline Quince & Iem & 5 & 4.4 & .4 & .7 & 3.4 & 2.9 & 2.2 & 2.5 & .6 & .7 & 0.1 & \\
\hline Redcurrant & ro & 0 & 6.3 & .9 & 1.8 & 3.0 & 2.5 & 1.9 & 2 & .1 & .1 & 0.1 & 0. \\
\hline Strav & 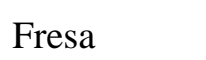 & 2.3 & 2.2 & 4.6 & .4 & 3.3 & 2.9 & 4.6 & 4.4 & .9 & .0 & 1 & 0 \\
\hline Watermelon & $s$ & .7 & 2.4 & .4 & .4 & 3.7 & 3.4 & 4.3 & 4.4 & .4 & .7 & 0.9 & 0. \\
\hline \multicolumn{14}{|l|}{ INSECTS } \\
\hline Ant & I & & 1.8 & 4.3 & 3 & 1.2 & 1.2 & 4.7 & 4.5 & 2 & 2 & 0.9 & 0. \\
\hline Bee & Abej & .9 & 2.8 & .5 & 3.6 & 1.2 & 1.2 & 4.2 & 4.3 & .5 & .5 & 0.5 & 0. \\
\hline utte & Iari & 3 & 2.3 & 4.0 & 3.8 & 1.1 & 1.1 & 4.1 & 3.9 & .5 & 6 & 0.9 & \\
\hline ach & c & 2 & 2.8 & 3.5 & 3.2 & 1.1 & 1.1 & 4.2 & 4.0 & 6 & .8 & 0.4 & 0.5 \\
\hline fly & ( & 4.3 & 4.3 & 2.5 & 2.5 & 1.1 & 1.0 & 3.4 & 3.1 & 3.5 & 3.3 & 0.4 & 0. \\
\hline ly & Ios & & 1.8 & 4.4 & 4 & 1.4 & 1.1 & 4.8 & 4.8 & 7 & 1 & 0.9 & 0 \\
\hline Mosquito & Mos & & 2.4 & 4.2 & & 1.4 & 1.2 & 4.6 & 4.8 & .6 & .5 & 0.5 & \\
\hline a. & 1 & 2.3 & 2.1 & 3.7 & 3.5 & 1.1 & 1.1 & 4.7 & 4.3 & 2.3 & 2.4 & 0.7 & 0. \\
\hline Termite & $\mathrm{T}$ & & 5.2 & 1.8 & & 1.2 & 1.0 & 2.8 & 2.8 & & 2.9 & 0.1 & \\
\hline Wasp & Avispa & 8 & 2.5 & 3.8 & 3.9 & 1.1 & 1.1 & 4.5 & 4.3 & .5 & .7 & 0.8 & \\
\hline \multicolumn{14}{|l|}{ TREES } \\
\hline Black & ho & & 5.0 & 2.5 & & 1.2 & 1.3 & 3.3 & 5.4 & & .1 & 0 & \\
\hline Cedar & 1 & 8 & 6.0 & 2.1 & 2.3 & 1.2 & 1.2 & 2.3 & 3.1 & .8 & 2.8 & 0 & 0. \\
\hline var & 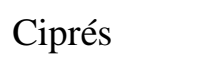 & 4.9 & 4.6 & 3.0 & 3.1 & 1.3 & 1.2 & 3.6 & 3.8 & 1.7 & 1.8 & 0.4 & 0. \\
\hline Fig tree & Hig & 4.6 & 4.5 & 2.6 & 2.9 & 1.8 & 1.7 & 3.0 & 3.4 & 2.9 & 2.8 & 0.0 & 0 . \\
\hline Fir & heto & 4 & 3.9 & 3.1 & 3.1 & 1.5 & 1.2 & 3.9 & 3.9 & 2.9 & 2.9 & 0.3 & 0.5 \\
\hline & Encina & 4.5 & 4.8 & 2.8 & 3.3 & 1.3 & 1.3 & 3.6 & 4.0 & 2.9 & 2.9 & 0.1 & 0 \\
\hline Olive tree & Olivo & 3.9 & 3.9 & 3.4 & 3.6 & 2.2 & 1.8 & 4.0 & 4.0 & 2.8 & 2.9 & 0.4 & 0. \\
\hline Palm tree & Dolmo & 3.2 & 3.2 & 3.6 & 3.8 & 1.5 & 1.4 & 3.7 & 3.8 & 3 & 2.8 & 0.9 & 0 . \\
\hline Pine tree & Pin & 2.9 & 3.1 & 3.8 & 4.1 & 1.2 & 1.2 & 4.6 & 4.6 & 1.9 & 2.1 & 0.3 & 0. \\
\hline Willow & Sauce & 4.6 & 4.9 & 3.0 & 2.8 & 1.3 & 1.3 & 3.5 & 3.2 & 3.2 & 3.1 & 0.8 & 0. \\
\hline \multicolumn{14}{|l|}{ VEGETAB } \\
\hline Artichoke & Alcachora & 3 & 3.8 & 3.6 & 3.8 & 3.4 & 3.3 & 3.8 & 3.6 & 2.3 & 2.5 & 0.8 & 0 \\
\hline
\end{tabular}




\begin{tabular}{|c|c|c|c|c|c|c|c|c|c|c|c|c|c|}
\hline Cabbage & epollo & 5.0 & 4.3 & 3.1 & 3.6 & 3.5 & 3.3 & 3.3 & 3.9 & 1.7 & 1.9 & 0.2 & 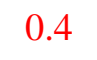 \\
\hline Cauliflower & Coliflor & 3.8 & 3.9 & 3.9 & 4.0 & 3 & 3.3 & 4.1 & 4.0 & 2.5 & 2.7 & 0.7 & \\
\hline Celery & Apio & .3 & 5.1 & .8 & 3.2 & 3.3 & 3.1 & 3.1 & 3.3 & 2.2 & 2.3 & 3 & \\
\hline Chard & celgas & .9 & 3.9 & .9 & 4 & .5 & 3.2 & 4.1 & 4.0 & 2.3 & 2.5 & .7 & \\
\hline Endive & scarola & 5 & 4.8 & .1 & 3.3 & 3 & .1 & .2 & .2 & 2.9 & 3 & .5 & \\
\hline Leek & uerro & 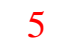 & 4.8 & .3 & .6 & .5 & 3.5 & 3.4 & 3.5 & 2.2 & 2.2 & .5 & \\
\hline Letucce & echuga & 2.7 & 2.6 & .6 & .7 & .6 & 3.3 & 4.7 & 4.7 & 1.9 & 2.1 & 9 & \\
\hline Spinach & spinacas & 9 & 8 & .4 & 9 & 3 & .1 & 4.0 & .2 & 2.3 & 2.5 & .3 & 6 \\
\hline & abo & 2 & .0 & 8 & .2 & .1 & .1 & 2.3 & 2.4 & 2.0 & 2.0 & 0 & \\
\hline \multicolumn{14}{|l|}{ BUILDING } \\
\hline Bunker & Bunquer & 6.0 & 5.8 & .5 & 1.4 & 2.2 & 2.3 & 1.5 & 1.3 & 3.8 & 3.1 & .2 & \\
\hline Castle & astillo & .8 & 2.6 & 5 & 4 & .8 & 1.9 & 3.2 & .0 & 3.2 & 3.1 & .8 & \\
\hline House & asa & 3 & 1.4 & 8 & 8 & .6 & 2.7 & 4.9 & .8 & 3.1 & 2.8 & .9 & 0.9 \\
\hline Igloo & glú & 4.0 & 4.2 & 2.2 & 2.1 & 2.7 & 2.7 & 2 & 1.8 & 1.6 & 1.7 & 9 & .9 \\
\hline NT & lórreo & .6 & 5.6 & .5 & 2.0 & 2.0 & 2.0 & 1.3 & 6 & .8 & .2 & .2 & \\
\hline agoda & agoda & 8 & 6.3 & .3 & 1.4 & .0 & 2.1 & 1.5 & .7 & .5 & .2 & .1 & \\
\hline Palace & io & 4 & 3.3 & 2.9 & 2.9 & 2.2 & 1.8 & 3.3 & .3 & 4.4 & 4.0 & .7 & \\
\hline Shanty & hab & 4.8 & 4.9 & 2.5 & 2.4 & 2.4 & 2.3 & 2.2 & 2.1 & 3.2 & 6 & .1 & \\
\hline Silo & $\cdot 1$ & .5 & 6.2 & 1.2 & 1.3 & .1 & 2 & 1.4 & 2 & 6 & .6 & .0 & \\
\hline Skyscraper & aci & 1.4 & 4.0 & 2 & 3.4 & .1 & 1.9 & 4.2 & 4.1 & 3 & .5 & .7 & \\
\hline \multicolumn{14}{|l|}{ CLOTHIN } \\
\hline Birreta & $e$ & .6 & 6.6 & 2.0 & 1.8 & 2.7 & 2.5 & 1.2 & 1.3 & 2.4 & 2.4 & 1 & \\
\hline Bov & ín & 3 & 5.1 & 2 & 2 & 8 & 3.0 & 2.0 & 1.9 & .5 & .6 & .3 & \\
\hline Coat & $A b_{1}$ & 2 & 2.1 & 5 & 4.4 & 3.3 & 3 & 4.6 & .6 & 2.2 & 2 & 0.9 & \\
\hline or & $\mathrm{Co}_{0}$ & .8 & 5.6 & 2.1 & 1.7 & 4.2 & 4.1 & 1.9 & 1.8 & 3.1 & 3.1 & 0.8 & 8 \\
\hline Fingerl & es & 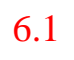 & 6.1 & 9 & 2.1 & .3 & 4.6 & 1.8 & .7 & 2.9 & .1 & 0.0 & 1. \\
\hline Hood & $\mathrm{Mu}$ & 6.8 & 6.9 & 1 & 1.2 & 2.9 & 2.9 & 1.1 & .2 & .9 & .0 & 0 & \\
\hline & & 5.3 & 5.5 & 2 & 1.8 & 3.3 & 3.3 & 1.8 & 2.1 & 3.5 & 3.5 & 0.6 & \\
\hline NT & $\mathrm{I}$ & 8 & 5.4 & & 1.7 & 3.2 & 3.2 & 1.7 & 1.9 & 8 & 2 & 0.0 & 0. \\
\hline Skirt & $\mathrm{F}$ & 2.2 & 2.0 & 4.6 & 4.6 & 3.5 & 3.0 & 4.7 & 4.8 & 1.1 & 1.3 & 0.9 & \\
\hline Socks & times & 17 & 17 & 9 & 8 & 8 & 3.5 & 4.3 & 4.3 & 2 & 1.4 & 0.9 & \\
\hline \multicolumn{14}{|l|}{ FURNITU } \\
\hline Bed & & 4 & 1.3 & 5 & 4.9 & 2.5 & 2.7 & 4.7 & 4.7 & 2.3 & 2.6 & 1 & \\
\hline Bec & & & 2.9 & 4.2 & 4.3 & 2.9 & 3.1 & 4.1 & 4.3 & 2.9 & 2.9 & 0.6 & \\
\hline & & & 3.6 & 4.4 & 4.4 & 3.2 & 3.3 & 4.1 & 4.1 & 3.5 & 3.5 & 0.6 & \\
\hline Bure & & 6.8 & 6.8 & 1.2 & 1.3 & 2.9 & 2.9 & 1.4 & 1.6 & 4.3 & 4.1 & 0 & \\
\hline Chest of & Cómoda & 6.2 & 6.0 & 2.7 & 2.0 & 1.7 & 1.9 & 2.5 & 2.3 & 3 & 3.0 & 0.6 & \\
\hline Coush & Diván & 4.7 & 5.0 & 7 & .6 & 3.6 & 3.1 & 3.7 & 3.6 & 2.1 & 2.2 & 0.3 & ). \\
\hline Filin & & 5.0 & 5.5 & 3.4 & 3.4 & 3.8 & 3.7 & 2.7 & 2.5 & 2.5 & 2.4 & 0.3 & \\
\hline Magazine & & 5.2 & 5.5 & 3.2 & 3.1 & 2.8 & 2.6 & 2.2 & 2.4 & 3.1 & 3.1 & 0.7 & \\
\hline Sideboard & Apara & 5.4 & 4.9 & 3.0 & 3.3 & 3.1 & 3.0 & 3.1 & 3.3 & 2.4 & 2.8 & 0.1 & \\
\hline Sofa & Sof & 2.1 & 2.5 & 4.8 & 4.8 & 1.7 & 2 & 4.7 & 4.8 & 2.2 & 2.3 & 0.8 & \\
\hline \multicolumn{14}{|l|}{ KITCHEN } \\
\hline Chinese & & . & 3.9 & 2.5 & 2.8 & 3.9 & 3.4 & 2.8 & 3.0 & 2.0 & 2 & 0.0 & \\
\hline Cooking & nero & 5.9 & 6.0 & 2.2 & 2.4 & 4.2 & 4.1 & 2.4 & 2.7 & 2.2 & 2.2 & 0.1 & \\
\hline Fondue & 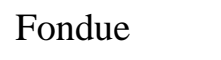 & 6.7 & 6.7 & 2.9 & 2.4 & 4.3 & 4.2 & 1.9 & 2 & 3.8 & 3.4 & 0.6 & \\
\hline ruit cor & Descorazon & 6.6 & 6.8 & 1.4 & 1.6 & 4.5 & 4.7 & 1.7 & 1.9 & 2.3 & 2.6 & 0 & 0 . \\
\hline 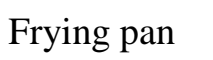 & & 3.0 & 2.7 & 4.7 & 4.8 & 4.4 & 4.3 & 4.9 & 4.8 & 1.7 & 1.8 & 1 & \\
\hline NT & Churrera & 5.8 & 5.4 & 1.5 & 1.8 & 4.6 & 4.5 & 1.5 & 1.8 & 3.4 & 3.2 & 0.0 & \\
\hline
\end{tabular}




\begin{tabular}{|c|c|c|c|c|c|c|c|c|c|c|c|c|c|}
\hline Peeler & Pelador & 5.5 & 5.8 & 2.9 & 2.9 & 4.8 & 4.7 & 2.8 & 2.9 & 2.5 & 2.6 & 0.3 & 0.4 \\
\hline Pot & Olla & 3.2 & 2.9 & 4.5 & 4.5 & 4.0 & 4 & 4.5 & 4.4 & 2.1 & 2.1 & 0.7 & 0.6 \\
\hline Saucepan & Cazo & 3.0 & 2.9 & 4.5 & 4.7 & 4.2 & 4.2 & 4.5 & 4.6 & 1.7 & 1.9 & 0.7 & 0.8 \\
\hline Sharpening & Chaira & 6.7 & 6.6 & 1.6 & 1.9 & 4.5 & 4.4 & 1.7 & 1.8 & 1.7 & 2.1 & 0.0 & 0.0 \\
\hline \multicolumn{14}{|l|}{ MUSICAL } \\
\hline Balalaika & Balalaica & 6.8 & 6.5 & 1.1 & 1.3 & 4.8 & 4.8 & 1.6 & 1.9 & 3.4 & 3.0 & 0.0 & 0.1 \\
\hline Clarinet & Clarinete & 5.0 & 5.5 & 2.5 & 2.3 & 4.9 & 4.7 & 3.4 & 3.4 & 3.4 & 3.2 & 0.5 & 0.5 \\
\hline Clavichord & Clavicordio & 6.6 & 6.7 & 1.2 & 1.3 & 4.6 & 4.8 & 1.8 & 2.2 & 4.0 & 4.0 & 0.1 & 0.2 \\
\hline Flute & Flauta & 3.0 & 2.9 & 3.6 & 3.7 & 4.9 & 4.7 & 4.4 & 4.4 & 1.5 & 1.8 & 1 & 1 \\
\hline Harp & Arpa & 4.3 & 4.4 & 2.5 & 2.3 & 4.8 & 4.9 & 3.4 & 3.5 & 3.4 & 3.3 & 0.8 & 0.9 \\
\hline Piano & Piano & 3 & 3 & 3.5 & 3.6 & 4.9 & 4.9 & 4.9 & 4.8 & 4.1 & 3.9 & 1 & 1 \\
\hline Saxophone & Saxofón & 4.4 & 5.0 & 2.9 & 2.6 & 4.9 & 4.7 & 4.0 & 3.8 & 4.1 & 4.0 & 0.8 & 0.8 \\
\hline Trumpet & Trompeta & 3.5 & 3.2 & 3.0 & 3.1 & 4.9 & 4.6 & 4.5 & 4.7 & 3.4 & 3.5 & 0.9 & 0.9 \\
\hline Tuba & Tuba & 5.9 & 6.4 & 2.2 & 1.6 & 4.7 & 4.6 & 2.8 & 2.8 & 3.8 & 3.8 & 0.1 & 0.1 \\
\hline Violin & Violín & 3.7 & 3.7 & 3.3 & 3.2 & 4.9 & 4.8 & 4.5 & 4.5 & 3.4 & 3.6 & 0.8 & 0.9 \\
\hline \multicolumn{14}{|l|}{ TOOLS } \\
\hline Bent gouge & Gubia & 6.8 & 6.7 & 1.4 & 1.3 & 4.5 & 4.8 & 1.8 & 2.0 & 2.4 & 2.5 & 0.0 & 0.0 \\
\hline Chisel & Formon & 6.3 & 6.2 & 2.0 & 2.2 & 4.4 & 4.5 & 2.5 & 2.6 & 1.5 & 1.5 & 0.1 & 0.1 \\
\hline Cold chisel & Cortafríos & 6.7 & 6.1 & 1.5 & 1.9 & 4.7 & 4.7 & 2.1 & 2.4 & 2.4 & 2.2 & 0.0 & 0.1 \\
\hline Handsaw & Serrucho & 4.1 & 3.8 & 3.3 & 3.4 & 4.8 & 4.7 & 4.1 & 4.1 & 1.6 & 1.8 & 0.3 & 0.6 \\
\hline Pickax & Alcotana & 6.7 & 6.2 & 1.7 & 2.2 & 4.7 & 4.8 & 2.2 & 2.5 & 1.9 & 1.9 & 0.0 & 0.0 \\
\hline Pincers & Alicates & 4.3 & 3.8 & 3.8 & 3.9 & 4.7 & 4.7 & 4.5 & 4.6 & 2.4 & 2.6 & 0.8 & 0.9 \\
\hline Pliers & Tenazas & 4.7 & 4.3 & 3.0 & 3.5 & 4.7 & 4.8 & 3.9 & 4.1 & 1.8 & 1.9 & 0.4 & 0.7 \\
\hline Screwdriver & Destornillad & 3.7 & 3.5 & 4.1 & 4.3 & 4.8 & 4.8 & 4.7 & 4.8 & 1.6 & 1.8 & 0.8 & 0.8 \\
\hline Shovel & Pala & 2.8 & 2.5 & 3.3 & 3.6 & 4.8 & 4.7 & 4.3 & 4.3 & 1.8 & 1.8 & 0.9 & 1 \\
\hline Trowel & Llana & 6.1 & 5.7 & 2.2 & 2.5 & 4.7 & 4.8 & 2.6 & 3.0 & 2.3 & 2.3 & 0.2 & 0.5 \\
\hline \multicolumn{14}{|l|}{ VEHICLE } \\
\hline Batiscaf & Batiscafo & 6.6 & 6.5 & 1.2 & 1.2 & 3.7 & 3.7 & 1.1 & 1.3 & 4.2 & 4 & 0.0 & 0.2 \\
\hline Bus & Autobús & 2.2 & 2.3 & 4.6 & 4.6 & 4.1 & 4.1 & 4.5 & 4.6 & 2.5 & 2.5 & 0.8 & 0.6 \\
\hline Car & Coche & 1.7 & 1.5 & 4.8 & 4.8 & 4.7 & 4.6 & 4.9 & 4.9 & 3.2 & 3.0 & 0.8 & 0.9 \\
\hline Glider & Planeador & 5.6 & 5.7 & 1.9 & 1.9 & 4.4 & 3.8 & 1.7 & 1.9 & 3.2 & 3.2 & 0.1 & 0.1 \\
\hline Hovercraft & Aerodesliza & 6.5 & 6.6 & 1.1 & 1.3 & 4.2 & 4.0 & 1.5 & 1.5 & 4.3 & 4.2 & 0 & 0.0 \\
\hline Kayak & Kayak & 6.6 & 6.3 & 1.5 & 1.4 & 3.6 & 3.7 & 1.2 & 1.4 & 3.3 & 3.0 & 0.0 & 0.0 \\
\hline Motorbike & Motocicleta & 2.1 & 2.0 & 4.5 & 4.3 & 4.6 & 4.6 & 4.7 & 4.6 & 3.8 & 3.7 & 1 & 1 \\
\hline Paragliding & Parapente & 5.8 & 6.4 & 2.4 & 2.2 & 4.2 & 4.1 & 1.4 & 1.4 & 3.2 & 3.3 & 0.4 & 0.5 \\
\hline Plane & Avión & 2.1 & 2 & 4.0 & 4.1 & 3.9 & 4 & 3.9 & 3.8 & 2.9 & 3.0 & 0.9 & 1 \\
\hline Train & Tren & 2.3 & 2 & 4.4 & 4.5 & 3.8 & 3.1 & 4.2 & 4.3 & 3.5 & 3.4 & 0.9 & 0.9 \\
\hline
\end{tabular}

Note: AoA = Age of acquisision; Fam = Familiarity, Man = Manipulability $;$ VC = Visual complexity; NA = Name agreement LF $=$ Lexical frequency. NT $=$ No translation into English. 
Appendix C. Proportion (in brackets) of target names, alternative names and acceptable synonims of each item.

\begin{tabular}{|c|c|c|}
\hline Item & Target name (Spanish) & $\begin{array}{l}\text { Alternative/synonims name-s } \\
\text { (Spanish) }\end{array}$ \\
\hline Cat & Gato (100) & \\
\hline Cow & Vaca (100) & \\
\hline Elephant & Elefante (100) & \\
\hline Genet & Jineta (44) & $\begin{array}{l}\text { Hiena (11), mofeta (6), comadreja (5), } \\
\text { lince (5), animal (3), huron (3), } \\
\text { felino(2), chinichilla (2), guepardo (2), } \\
\text { lirón (2), mamifero (2), mandril (2), } \\
\text { mangosta (2), mapache (2), marsupial } \\
\text { (2), marta (2), raposa (1), tapir (1), } \\
\text { hurón (1), lemur (1). }\end{array}$ \\
\hline Hen & Gallina (85) & Gallo (15). \\
\hline Kangaroo & Canguro (100) & \\
\hline Kiwi & Kiwi (34) & $\begin{array}{l}\text { Pollo (30), pájaro (13), ave (12), pato } \\
(4) \text {, ibis (3), cigueña (2), jilguero (2). }\end{array}$ \\
\hline Ray & Raya (35) & $\begin{array}{l}\text { Manta (33), hoja (11), babosa ( } 7) \text {, } \\
\text { nenufar (4), águila de mar (2), caracol } \\
\text { (2), cochinillo (2), hueso (2), pimiento } \\
\text { (2). }\end{array}$ \\
\hline Rhino & Rinoceronte (98) & Hipopótamo (2). \\
\hline Tapir & Tapir (33) & $\begin{array}{l}\text { Oso hormiguero (33), oso (10), } \\
\text { ornitorrinco (9), ocapi ( } 7) \text {, armadillo } \\
\text { (2), cerdo (2), elefante (2), jabato (1), } \\
\text { manatí (1). }\end{array}$ \\
\hline Cerebelum & Cerebelo (25) & $\begin{array}{l}\text { Cerebro (36), encéfalo (6), víscera (6), } \\
\text { carne (4), intestinos (4), páncreas (4), } \\
\text { sesos (4), callos (2), corazón (2), } \\
\text { chuleta (2), hígado (2), lengua (2), } \\
\text { piedra (1), ventrículo (1). }\end{array}$ \\
\hline Foot & Pie (100) & \\
\hline Hand & Mano (99) & Uñas (1). \\
\hline Kidney & Riñón (74) & $\begin{array}{l}\text { Judía (13), haba (3), pulmón (3), } \\
\text { habichuela (2), hígado (2), alubia (1), } \\
\text { carne (1), feto (1). }\end{array}$ \\
\hline Leg & Pierna (98) & Extremidad (1), medias (1). \\
\hline
\end{tabular}


Liver

Hígado (80)

Lung

Pulmón (43)

Pelvis

Pelvis (36)

Skull

Vertebra

Araceae

Bellflowers

Carnation

Daisy

Geranium

Orchid

Pansy

Poppy

Rose

Tulip

Blueberry
Vértebra (66)

Cala (21)

Pensamiento (36)

Cráneo (42)

Campanillas (25)

Clavel (91)

Margarita (97)

Geranio (20)

Orquídea (36)

Amapola (90)

Rosa (98)

Tulipán (66)

Arándanos (14)
Corazón (5), pulmón (5), riñón (4), víscera (2), carne (1), chocolate (1), páncreas (1), pimiento (1).

Hígado (31), riñón (10), corazón (6), víscera (3), lengua (2), molleja (2), páncreas (2), carne (1).

Cadera (48), cocsis (7), esqueleto (2), hueso (2), clavícula (1), esternón (1), fémur (1), médula (1), vértebra (1).

Calavera (56)***, cabeza (1), esqueleto (1).

Hueso (22), pelvis (4), atlas (1), canal (1), clavícula (1), coxis (1), esfenoides (1), isquión (1), médula (1), rodilla (1).

Flor (21), lirio (22), gladiolo (10), tulipán (8), azucena (6), orquídea (4), petunia (3), amapola (1), cartucho (1), jazmín (1), nardo (1), pistilo (1).

Flor (23), violetas (16), lila (14), lirio (10), tulipán (5), jazmín (3), orquídea (3), digital (1).

Flor (5), geranio (2), rosa (1), ramo (1). Amapola (1), manzanilla (1), flor (1).

Flor (42), rosa (15), ramo (8), clavel (6), ramillete (5), lirios (1), orquídea (1), petunias (1)

Flor (47), violeta (7), lirio (3), pensamiento (3), azahar (1), boca de dragón (1), lilium (1), petunia (1).

Flor (45), orquídea (10), begoña (4), amapola (1), campanilla (1), dalia (1), geranio (1), pétalos (1)

Flor (5), tulipán (3), rosa (2).

Capullo (1), flor (1).

Amapola (19), rosa (6), flor (6), lirio (2), petunia (1).

Ciruelas (31), tomates (14), castañas (11), endrinas (6), aceituna (3), cajas (3), canicas (3), fruta (3), granadas (3), guindas (3), higos (3), verdura (3). 
Melon

Melón (99)

Papaya

Peach

Pear

Quince

Redcurrant

Strawberry

Watermelon

Ant

Bee

Butterfly

Cockroach

Dragonfly

Fly

Mosquito

Spider

Termite
Melocotón (87)

Grosella (36)

Papaya (14)

Pera (100)

Membrillo (41)

Fresa (95)

Sandía (94)

Hormiga (97)

Abeja (64)

Mariposa (100)

Cucaracha (63)

Libélula (58)

Mosca (97)

Mosquito (83)

Araña (83)

Termita (47)
Granada (15), caqui (15), mango (8), naranja (6), fruta (5), aki (5), pomelo (3), albaricoque (2), datil (2), higo (2), papaya (1), pera (1), tomate (1).

Sandía (1).

Mango (24), limón (21), aguacate (18), pera (7), pomelo (7), fruta (4), lima (4), higo (1).

Manazana (5), pomelo (3), albaricoque (1), ciruela (1), fruta (1), mango (1), membrillo (1).

Manzana (29), pomelo (16), limón (8), calabaza (2), lima (2), caquis (1), fruta (1).

Arándano (12), cerezas (11), uva (11), endrinas (7), fruto (6), bayas (6), tomates (5), ciruelas (1), cranberrys (1), frambuesas (1), fruta (1), guindas (1), racimo (1).

Fresón $(5)^{* * *}$

Melón (6).

Araña (3).

Mosca (17), abejorro (6), moscardón (4), insecto (4), avispa (2), abejaruco (1), moscón (1), araña (1).

Escarabajo (17), grillo (16), insecto (3), bicho (1).

Mariposa (36), insecto (3), polilla (2), luciérnaga (1).

Abjeja (1), mosquito (1), moscardón (1)

Libélula (6), insecto (5), bicho (1), coleóptero (1), insecto (1), madreagua (1), picatel (1), zapatero (1).

Tarántula (16)***, alacrán (1).

Hormiga (17), insecto (10), larva (10), bicho (8), gusano (3), abeja (2), ladilla (2), oruga (1). 


\begin{tabular}{|c|c|c|}
\hline Wasp & Avispa (90) & Abeja (10). \\
\hline Black poplar & Chopo (1) & $\begin{array}{l}\text { Ciprés (43), pino (26), abeto (14), } \\
\text { árbol (7), álamo (3)***, arbusto (1), } \\
\text { arizónica (1), cedro (1), helecho (1), } \\
\text { sauce (1), seto (1). }\end{array}$ \\
\hline Cedar & Cedro (1) & $\begin{array}{l}\text { Abeto (58), pino (36), árbol (3), ciprés } \\
\text { (1), chopo (1). }\end{array}$ \\
\hline Cypress & Ciprés (61) & $\begin{array}{l}\text { Pino (21), abeto (9), árbol (4), álamo } \\
\text { (1), arbusto (1), conífera (1), helecho } \\
\text { (1), sauce (1). }\end{array}$ \\
\hline Fig tree & Higuera (5) & $\begin{array}{l}\text { Árbol (45), naranjo (13), encina ( } 7) \text {, } \\
\text { frutal (5), manzano (5), olivo (5), } \\
\text { almendro (4), castaño (1), cerezo (1), } \\
\text { ciprés (1), ciruelo (1), chopo (1), } \\
\text { guindo (1), haya (1), limonero (1), } \\
\text { nogal (1), olmo (1), sauce (1). }\end{array}$ \\
\hline Fir & Abeto (53) & $\begin{array}{l}\text { Pino (30), árbol (8), cedro (4), ciprés } \\
\text { (1), arbusto (1), arce (1), abedul (1), } \\
\text { sauce (1). }\end{array}$ \\
\hline Holm oak & Encina (40) & $\begin{array}{l}\text { Olivo (21), árbol (18), alcornoque (4), } \\
\text { nogal (4), bonsai (3), roble (3), } \\
\text { bellotero (1), carrasca (1), castano (1), } \\
\text { chopo (1), ciprés (1), haya (1), pino } \\
\text { (1). }\end{array}$ \\
\hline Olive tree & Olivo (51) & $\begin{array}{l}\text { Encina (18), árbol (17), alcornoque (2), } \\
\text { ciprés (2), roble (2), abeto (1), } \\
\text { aceitunero (1), álamo (1), copa (1), } \\
\text { haya (1), manzano (1), olmo (1), tilo } \\
\text { (1). }\end{array}$ \\
\hline Palm tree & Palmera (97) & Árbol (1), chopo (1), pino (1). \\
\hline Pine tree & Pino (73) & $\begin{array}{l}\text { Árbol (22), encina (2), arbusto (1), } \\
\text { chopo (1), conífera (1). }\end{array}$ \\
\hline Willow & Sauce (85) & $\begin{array}{l}\text { Árbol (11), cedro (1), chopo (1), fresno } \\
\text { (1), roble (1). }\end{array}$ \\
\hline Artichoke & Alcachofa (94) & $\begin{array}{l}\text { Alcucil (2)***, berenjena (1), } \\
\text { chirimoya (1), coliflor (1), espárrago } \\
\text { (1). }\end{array}$ \\
\hline Cabbage & Repollo (32) & $\begin{array}{l}\text { Col (34), lechuga (23), coliflor (5), } \\
\text { berza (3), cogollo (1), escarola (1), } \\
\text { verdura (1). }\end{array}$ \\
\hline Celery & Apio (57) & $\begin{array}{l}\text { Perejil (17), puerro (7), acelga (6), } \\
\text { borraja (4), ajos (2), rábano (2), cardo } \\
\text { (1), cebolla (1), hortaliza (1), nabo (1), } \\
\text { vegetal (1). }\end{array}$ \\
\hline
\end{tabular}


Chard

Acelgas (77)

Cauliflower

Coliflor (86)

Endive

Leek

Lettuce

Spinach

Turnip

Castle

House

Igloo

Hórreo*

Pagoda

Palace

Shanty

Castillo (97)
Chabola (15)

Escarola (74)

Puerro (70)

Lechuga (96)

Espinacas (63)

Nabo (42)

Bunquer (69)

Casa (92)

Iglú (97)

Hórreo (81)*

Pagoda (49)

Palacio (93)

Silo (4)
Lechuga (14), espinacas (4), verdura (2), apio (1), brócoli (1), grelos (1).

Col (11), repollo (3).

Lechuga (11), col (8), brécol (2), arbusto (1), coliflor (1), hortaliza (1), repollo (1) verdura (1).

Cebolleta (8), ajo (6), apio (6), rábano (3), cebollino (2), nabo (2), ajetes (1), cebolla (1), hortaliza (1).

Acelga (1), ensalada (1), espinacas (1), verdura (1).

Acelga (21), lechuga (7), berza (2), Berros (1), canónigos (1), col (1), grelos (1), vegetal (1), verdura (1).

Patata (34), tubérculo (8), batata (2), chirimolla (2), fruto (2), garrapata (2), kiwi (2), limón (2) manzana (2), puerro (2)

Horno (8), refugio (5), cueva (3), casamata (3), cabaña (2), casa (2), caseta (2), fortín (2), monumento (2), nevera (1), yurta (1).

Muralla (1), almena (1), fortaleza (1).

Chalet (6), caserío (1), fachada (1).

Casa esquimal (1), cueva (1), iceberg (1).

Casa (5), palomar (4), avispero (4), caseta (1), edificio (1), granero (1), urna (1), iglesia (1), nido (1).

Torre (17), templo chino (14), casa (10), edificio (6), palacio (3), palacete (1).

Mansión (3), monasterio (2), edificio (1), museo (1).

Casa (40), cabaña (14), caseta (12), choza (4), chamizo (3), cobertizo (3), barraca (2), establo (2), camping (1), cuadra (1), hangar (1), pajar (1), tienda (1).

Faro (41), torre (37), edificio (6), rascacielos (4), chimenea (3), monumento (3), cohete (2). 
Skyscraper

Birreta

Bowler hat

Coat

Corset

Fingerless

glove

Hood

Kimono

Pololos*

Socks

Bed

Bedside table

Bookcase

Bureau

Chest of

drawer
Librería (76)

Bargueño (6)

Birrete (61)

Bombín (34)

Abrigo (97)

Corsé (85)

Mitones (7)

Muceta (3)

Quimono (83)

Pololos (29)*

Falda (98)

Calcetines (100)

Cama (100)

Mesilla (76)

Cómoda (42)
Edificio (12), torres (11), cuzco (1).

Gorro (19), bonete (4)***, borla (4), orla (4), sombrero (4), toga (4)

Sombrero $(66)^{* * *}$

Chaquetón (1), gabardina (1), vestido (1)

Corpiño (9), faja (3), carcasa (1), refajo (1), vestido (1).

Guantes (54), manoplas (37),

calentadores (1), manguito (1).

Toga (27), capa (24), falda (7), prenda (6), babero (3), capelina (3), casucha (3), casulla (3), chal (3), pechera (1), poncho (3), ropa (3), sayi (3), top (3), toquilla (3), vitola (3)

Vestido (5), bata (4), ropa (4), mono (2), albornoz (1), pijama (1).

Enagua (30), calzones (14), polaina (8), pantalón (7), bombachos (3), pijama (3), calzas (2), bragas (1), polainas (1), piratas (1), zaraguelles (1)

Bermuda (1), pantalón (1).

Cómoda (4), mueble (3), aparador (3), cajonera (3), mesa (3), cajones (1), consola (1), encimera (1), sinfonier (1), taquillón (1), tocador (1), velador (1), zapatero (1).

Estantería (10), biblioteca (6), vitrina (4), armario (3), mueble (1).

Escritorio (21), mueble (16), secreter (11), armario (6), cómoda (6), joyero (6), alcoba (2), arcón (2), aparador (2), buró (2), cajonera (2), coqueta (2), encimera (2), escribano (2), máquina (2), mesilla (2), mesita (2), sinfonier (2), taquillón (2), tocador (2).

Cajonera (34), mesilla (6), cajones (4), clasificador (3), mueble (3), archivo (2), book (2), fichero (2), mesa (1), revistero (1) 
Couch

Diván (65)

Filing cabinet

Archivador (42)

Magazine

rack

Sideboard

Sofa

Chaira*

Chino*

Churrera*

Cooking pot

Fondue

Fondue (88)

Fruit corer

Frying pan

Peeler

Pelador (64)

Churrera (63)*
Sofá (16), chaislonge (13)***, sillón

(2), canapé (1), cómoda (1),

descalzador (1), tumbona (1)

Cajonera (34), mesilla (6), cajones (4), clasificador (3), mueble (3), archivo (2), book (2), fichero (2), mesa (1), revistero (1).

Mueble (2), hamaca (1), columpio (1), portador (1), portarevistas (1), telar (1).

Cómoda (30), mueble (12), tocador (7), sinfonier (5), taquillón (4), armario (3), mesita (3), consola (2), escritorio (2), alcoba (1), buró (1), comodín (1), encimera (1), recibidor (1).

Tresillo (9), sillón (8).

Afilador (42)***, lima (37), punzón

(5), destornillador (2), lija (2), eslabón (1), herramienta (1), mechador (1), picahielos (1), trinchador (1).

Embudo (44)***, pasapuré (2), cazo (1), cono (1), cubeta (1), espumadera (1).

Sacacorchos (10), grifo (9), manga (6), picador (3), pimentero (3),

salpimentador (3), silbato (3).

Jarra (15), tetera (14), taza (5), cazuela (4), olla (4), bote (3), cafetera (3), cazo (3), jarrón (3), lechera (3), pote (3), aceitera (1), azucarero (1), botijo (1), cacerola (1), cueceleche (1), envase (1), lata (1), recipiente (1), tarro (1), tinaja (1), tetera (1), vasija (1).

Cenicero (3), olla (3), adorno (1), brasero (1), freidora (1), portabolígrafos (1), suiza (1), tetera (1).

Pelador (33), formón (11), gubia (8), lima (8), pelapatatas (8), cincel (6), destornillador (6), vaciador (6), escoplo (3), herramienta (3), lezna (2).

Pelapatatas (27)***, mondador (3), cortador (2), estilete (1), herramienta (1), mechador (1), vaciador (1). 
Saucepan

Balalaika

Clarinet

Clavichord

Clavicordio (21)

Flute

Harp

Piano

Saxophone

Trumpet

Tuba

Violin

Bent gouge

Cold chisel
Cazo (80)

Balalaica (19)

Clarinete (64)

Flauta (100)

Arpa (97)

Piano (100)

Saxofón (91)

Trompeta (97)

Tuba (18)

Violín (86)

Gubia (13)

Formón (18)

Cortafríos (27)

Serrucho (46)
Cacerola (21), cazuela (8), puchero (2), pota (1), recipiente (1), sopera (1).

Cacerola (8), cazuela (5), olla (3), cacillo (1), puchero (1), recipiente (1), sartén (1).

Laúd (27), guitarra (24), bandurria (8), mandolina (8), bango (4), instrumento (4), cítara (4), clavicordio (2).

Flauta (24), flautín (3), oboe (3), saxofón (2), trompetín (2), cornetín (1), instrumento (1).

Piano (47), órgano (8), pianola (7), clave (6), clavecín (4), pianola (2), clavicénvalo, espineta (1)***, (1), mesa (1), musical (1), tocador (1).

Acordeón (1), arpón (1), lira (1).

Trompeta (9).

Saxofón (2), corneta (1).

Trombón (49), trompeta (16), saxofón (7), trompa (7), balalaica (1), bombardino (1), cuerno (1).

Violoncelo (8), viola (4), contrabajo (1), guitarra (1)

Lima (30), formón (11), cincel (8), herramienta (9), buril (5), destornillador (4), calzador (2), debastador (2), escofina (2), escoplo (2), lija (2), pelador (2), punzón (2), rayador (2), sacahuesos (2), vaciador (2)

Lima (45), cincel (9), escoplo (9), espátula (7), lija (6), gubia (3), escofina (1), herramienta (1), rascador (1).

Cincel (38), escoplo (13), lima (5), palanca (3), puntero (3), catana (1), clavo (1), estaca (1), formón (1), funda (1), herramienta (1), mazo (1), pica (1), punta (1), punzón (1), vara (1).

Sierra (53), hacha (1) 
Pincers

Pliers

Screwdriver

Shovel

Trowel

Batiscaf

Bus

Car

Glider

Hovercraft

Motorbike

Paragliding

Plane

Train
Alicates (96)

Tenazas (72)

Destornillador (90)

Pala (99)

Llana (60)

Batiscafo (21)

Autobús (82)

Coche (84)

Planeador (17)

Aerodeslizador (2)

Kayak (4)

Motocicleta (100)

Parapente (55)

Avión (100)

Tren (94)
Pico (40), piqueta (17), martillo (16), azada (7), picoleta (6), picota (3), piolet (3), zacho (2).

Tenazas (4).

Alicate (26), llave inglesa (1), pinzas (1).

Punzón (5), atornillador (3)***, buril (1), herramienta (1).

Paleta (1).

Paleta (10), espátula (8), alisador (8), plana (6), lija (4), allanador (1), aplanador (1), palaustre (1), rasilla (1).

Submarino (73), aeronave (3), motor (1), oceanógrafo (1), sumergible (1), turbina (1)

Autocar (17)****, vagón (1).

Peugeot-207 (10)***, automóvil

(4) $* * *$, turismo $(2) * * *$

Avioneta (36), aeoroplano (17), avión (17), ultraligero (10), aeromodelismo (1), dirigible (1), helicóptero (1).

Hovercraft (56)**/***, lancha (6), barco (4), quitanieves (4), aircraft (3), anfibio (3), apisonadora (2), barca (2), cliper (2), coche acuático (2), deslizador (2), máquina (2), oruga (2), motora (2), overtank (2), reactor (2), zodiac (2).

Canoa (54), piragua (30), góndola (5), barca (3), barco (1), cayuco (1), incienso (1), lancha (1).

Paracaidas (42), paramotor (2), aladelta (1)

Metro (6)

Note: $*$ Not possible to transladate into English. ${ }^{* *}=$ Most of the participants gave an English name to the object. In the present case, the item (aerodeslizador) can be acceptably called with an English word (hovercraft), according to Spanish gramatical rules. *** Acceptable synonym. 